KEY WORDS: DOE-HQ

In situ Decommissioning Entombment

Workshop

\title{
TECHNOLOGY REQUIREMENTS FOR IN SITU DECOMMISSIONING (ISD) WORKSHOP REPORT
}

\author{
Patricia L. Lee, John B. Gladden, G. Timothy Jannik, \\ Christine A. Langton, Michael G. Serrato, SRNL \\ Chuck Urland, Erick Reynolds, PEC
}

June 2009

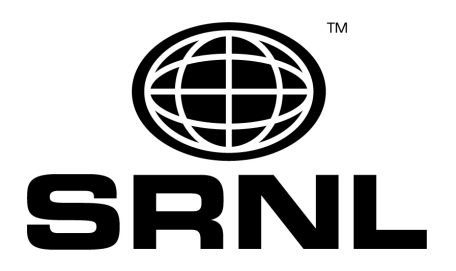

Savannah River National Laboratory Savannah River Nuclear Solutions Savannah River Site Aiken, SC 29808

This document was prepared in conjunction with work accomplished under Contract No. DE-AC09-08SR22470 with the U.S. Department of Energy 


\section{DISCLAIMER}

This work was prepared under an agreement with and funded by the U.S Government. Neither the U. S. Government or its employees, nor any of its contractors, subcontractors or their employees, makes any express or implied: 1 . warranty or assumes any legal liability for the accuracy, completeness, or for the use or results of such use of any information, product, or process disclosed; or 2. representation that such use or results of such use would not infringe privately owned rights; or 3. endorsement or recommendation of any specifically identified commercial product, process, or service. Any views and opinions of authors expressed in this work do not necessarily state or reflect those of the United States Government, or its contractors, or subcontractors. 


\section{TABLE OF CONTENTS}

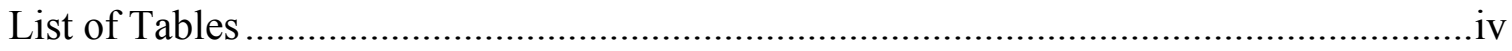

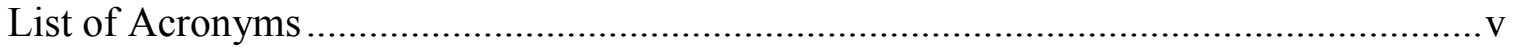

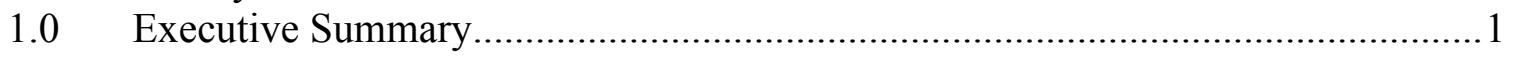

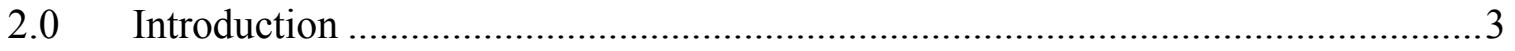

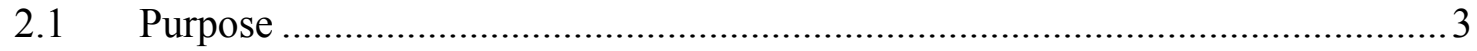

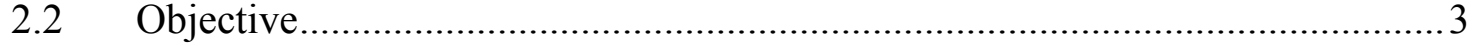

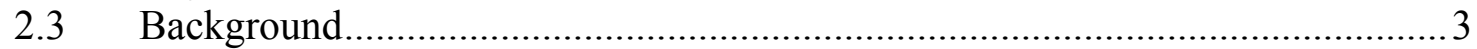

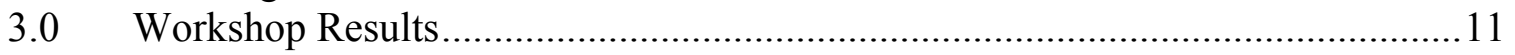

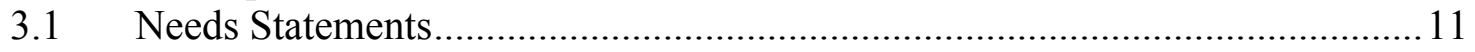

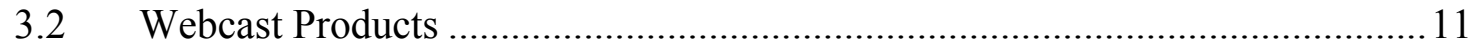

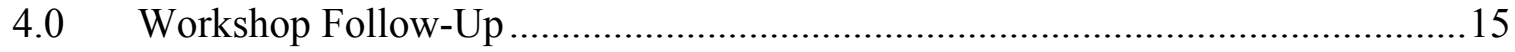

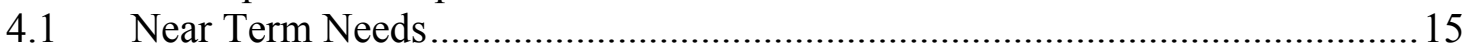

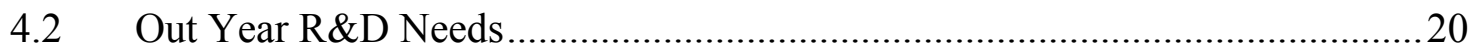

4.3 Functional Requirements for Related Efforts ................................................2

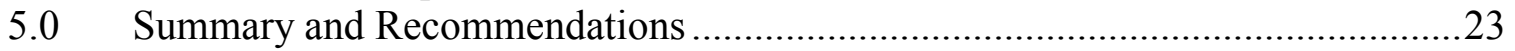

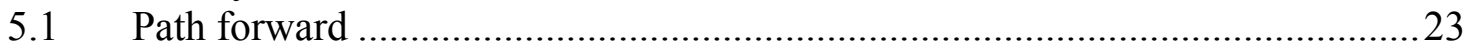

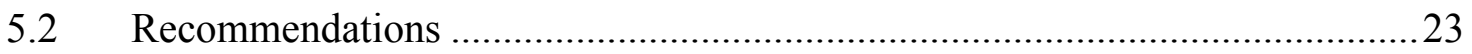

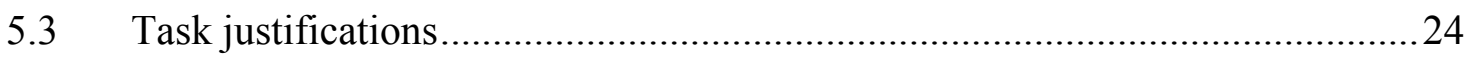

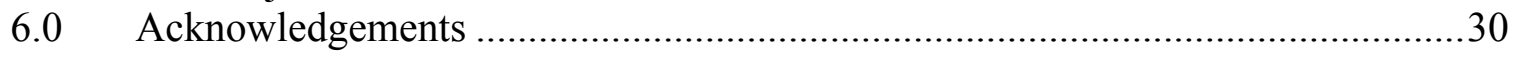

Appendix A. ISD Technical Challenges Detailed Issues...............................................31

Appendix B. ISD Workshop Attendee Contact Information .........................................33

Appendix C. Workshop Needs Statements Details.......................................................37

C.1 Need 1: In-Tank Characterization with Isotopic Discrimination ........................37

C.2 Need 2: Assessment of the State-of-the-Art for Field Deployment Systems for

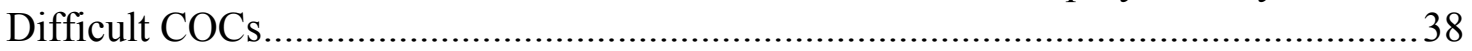

C.3 Need 3: Degradation Rates and Sorption Behavior...........................................39

C.4 Need 4: Long Term Materials Performance Studies ……………………….... 40

C.5 Need 5: Release of Activation Products from Corroded Stainless Steel........... 42

C.6 Need 6: Design Guide for Sealing/Filling ISD Facilities ..................................43

C.7 Need 7: Seal/Fill Material 'Toolbox' .............................................................4 44

C.8 Need 8: Energy and Environmentally Responsive Fill Material Designs ..........47

C.9 Need 9: Design Monitoring Into ISD Facility .................................................47

C.10 Need 10: Measures to Improve Communication of Risk Assessment Modeling

Approaches, Data and Lessons Learned ..................................................................50

C.11 Need 11: Technical Resources Needed for ISD .............................................51

C.12 Need 12: Problem: Significant Sample Analysis Is Required to Establish Ratios

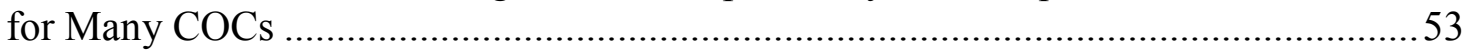

C.13 Need 13: DOE Order 470.4-6 Nuclear Material Control and Accountability...54

C.14 Need 14: Develop and Test Flowable Concrete/Grout Mixes for ISD Applications. 


\section{LIST OF TABLES}

Table 1. Generalized Technical Challenges for ISD ……….....................................

Table 2. ISD Workshop Technical Participants ........................................................

Table 3. ISD Workshop Agenda........................................................................ 8

Table 4. Initial Breakout Session Topics and Groups .................................................

Table 5. ISD Needs Statements Summary................................................................ 12

Table 6. Technology Development Topics for SRS Reactor ISD Projects ..................17

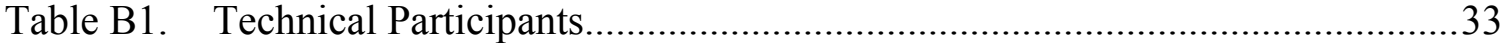

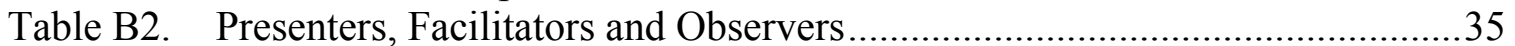




\section{LIST OF ACRONYMS}

\begin{tabular}{|c|c|}
\hline ALARA & As Low as Reasonably Achievable \\
\hline ARRA & American Recovery and Reinvestment Act \\
\hline CBP & Cementitious Barriers Partnership Project \\
\hline CERCLA & Comprehensive Environmental Response, Compensation, and Liability Act \\
\hline $\mathrm{CDF}$ & Controlled Density Fill \\
\hline CDI & Canyon Disposition Initiative \\
\hline CHR & Center for Hydrogen Research \\
\hline $\mathrm{COCs}$ & Contaminants of Concern \\
\hline COP & Community of Practice \\
\hline CPRC & CH2M Hill Plateau Remediation Company \\
\hline CRESP & Consortium for Risk Evaluation with Stakeholder Participation \\
\hline CWI & CH2M-WG Idaho \\
\hline D\&D & Deactivation and Decommissioning \\
\hline DOE & Department of Energy \\
\hline EAROD & Early Action Record of Decision \\
\hline EFCOG & Energy Facility Contractors Group \\
\hline $\mathrm{ECN}$ & Energy Research Center of the Netherlands \\
\hline EM & Environmental Management \\
\hline FIU & Florida International University \\
\hline HEPA & High Efficiency Particulate Air \\
\hline HQ & Head Quarters \\
\hline INL & Idaho National Laboratory \\
\hline ISD & In Situ Decommissioning \\
\hline KM-IT & Knowledge Management-Information Tool \\
\hline LEED & Leadership in Energy and Environmental Design \\
\hline LLW & Low Level Radioactive Waste \\
\hline LTM & Long Term Monitoring \\
\hline NEPA & National Environmental Policy Act \\
\hline NIST & National Institute of Standards and Technology \\
\hline NRC & Nuclear Regulatory Commission \\
\hline ORNL & Oak Ridge National Laboratory \\
\hline PA & Performance Assessment \\
\hline PEC & Project Enhancement Corporation \\
\hline PUREX & Plutonium and Uranium Extraction \\
\hline RCRA & Resource Conservation and Recovery Act \\
\hline RL & Richland Operations Office \\
\hline SME & Subject Matter Expert \\
\hline SNM & Special Nuclear Material \\
\hline SRNL & Savannah River National Laboratory \\
\hline SRNS & Savannah River Nuclear Solutions \\
\hline SRS & Savannah River Site \\
\hline TRU & Transuranic \\
\hline USGBC & United States Green Building Council \\
\hline VU & Vanderbilt University \\
\hline
\end{tabular}


This Page Intentionally Left Blank 


\subsection{EXECUTIVE SUMMARY}

In recognition of the increasing attention being focused on In Situ Decommissioning (ISD or entombment) as an acceptable and beneficial decommissioning end state, the Department of Energy's (DOE) Office of Environmental Management (EM) is developing guidance for the implementation of ISD of excess facilities within the DOE complex. Consistent with the overarching DOE goals for increased personnel and environmental safety, reduced technical uncertainties and risks, and overall gains in efficiencies and effectiveness, EM's Office of Deactivation and Decommissioning and Facility Engineering (EM-23) initiated efforts to identify the technical barriers and technology development needs for the optimal implementation of ISD.

Savannah River National Laboratory (SRNL), as the EM Corporate Laboratory, conducted an ISD Technology Needs Workshop to identify the technology needs at DOE sites. The overall goal of the workshop was to gain a full understanding of the specific ISD technical challenges, the technologies available, and those needing development. The ISD Workshop was held December 9-10, 2008 in Aiken, SC. Experienced decommissioning operations personnel from Richland Operations Office (RL), Idaho National Laboratory (INL) and Savannah River Site (SRS) along with scientists and engineers specific expertise were assembled to identify incremental and 'game changing' solutions to ISD technology challenges. The workshop and follow-up activities yielded 14 technology needs statements and the recommendation that EM-23 prioritize and pursue the following specific technology development and deployment actions. For each action, the recommended technology acquisition mechanisms (competitive solicitation (CS) or direct funding (TCR)) are provided. Activities that are time critical for ISD projects, or require unique capabilities that reside in the DOE Laboratory system will be funded directly to those institutions. Activities that have longer lead times and where the private sector, universities or other agencies are expected to have greater expertise will be accomplished through an open, competitive solicitation process. Several areas will require joint efforts from the two classes of resources.

1. Develop and demonstrate new and alternative fill materials
a. Ceramicrete testing of "non-alkaline fill" for reactor vessel ISD (TCR)
b. Highly flowable concrete and grout mixtures
(TCR,CS)
c. Alternative "Green" fill materials
(CS)

2. Select (and/or develop) and deploy a suite of sensors to verify the performance of nearterm ISD projects (subsidence, stress/strain, and fractures)

(TCR,CS)

3. Develop an ISD-specific performance model
a. Develop ISD-specific conceptual site model
(TCR,CS)
b. Incorporate performance verification dataset from P\&R ISD
c. Perform sensitivity analyses to identify suite of key parameters
(TCR,CS)
d. Identify data quality objectives for key parameters
(TCR,CS)

4. Define and quantify the degradation rates and release mechanisms for
a. concrete structures
(CS)
b. activation products from steel
(CS)
c. fill materials

5. Develop and deploy state of the art characterization instrumentation
a. Difficult to sample locations (tanks and sumps)
b. Difficult to measure contaminants (long-lived, low-energy)
c. Develop indicator contaminant or isotopic ratios

(TCR,CS)

(TCR,CS) 
This Page Intentionally Left Blank 


\subsection{INTRODUCTION}

In recognition of the increasing attention being focused on In Situ Decommissioning (ISD or entombment) as an acceptable and beneficial decommissioning end state, the Department of Energy's (DOE) Office of Environmental Management (EM) is developing guidance for the implementation of ISD for an appropriate, but relatively small (100-150), set of excess facilities within the DOE complex. Consistent with the overarching Departmental goals for increased personnel and environmental safety, reduced technical uncertainties and risks, and overall gains in efficiencies and effectiveness, EM's Office of Engineering and Technology (EM-20) - Office of Deactivation and Decommissioning and Facility Engineering (EM-23) has initiated efforts to identify the 1) technical barriers and gaps and 2) concomitant technology development needs for the optimal implementation of ISD.

Savannah River National Laboratory (SRNL), as the EM Corporate Laboratory, was tasked by EM-23 with conducting an In Situ Decommissioning (ISD) Technology Needs Workshop to support this effort and identify the technology needs at DOE sites. The overall goal of the workshop is to gain a full understanding of the specific technical challenges surrounding ISD, the technologies available, and those needing development. SRNL conducted this workshop on December 9-10, 2008, at the Center for Hydrogen Research in Aiken, SC, with technical support services from Project Enhancement Corporation (PEC). The subsequent four months have entailed analysis of the identified technical challenges, preliminary literature research regarding available technologies, and evaluation on research and development and/or adaptations of potentially applicable technologies.

\subsection{PURPOSE}

This report documents the workshop results and provides recommendations for a path forward.

\subsection{OBJECTIVE}

The objective of the workshop was to define the ISD technical challenges and explore potential investment opportunities in technical breakthroughs that will:

- Improve characterization of existing conditions within ISD candidate facilities.

- Shorten time, lower costs, and reduce risks in the execution of ISD work activities.

- Add confidence to the long term durability of the resultant entombment structure.

\subsection{BACKGROUND}

ISD is an alternative strategy being considered by the DOE as a decommissioning option for the safe and cost effective disposition of robust nuclear facilities built during the Cold War. The ISD option entails the entombment of especially (but not necessarily limited 
to) the subsurface portion of these massive nuclear buildings on the DOE enduring sites. This disposition option eliminates the high costs and hazards associated with excavation, demolition, transportation and re-interment of low-level contaminated rubble. It has been estimated that cost reductions of over $\$ 2$ billion $(\$ 2 B)$ are feasible at facilities meeting the criteria (currently being developed) for ISD.

To date, only a limited number of facilities have been placed or are currently in various stages of planning and implementation for ISD at INL, Hanford, and Savannah River. The U-Canyon (Building 221-U) is one of five very large, reinforced concrete structures at Hanford that was chosen as the initial facility for the Canyon Disposition Initiative (CDI), which began in 1995. A CERCLA ROD for the cleanup of Building 221-U was issued in October 2005. The selected remedy consolidates equipment into below-grade cells, partially demolishes the above-grade structure with the remainder being filled with grout, and utilizes an engineered cover system over the entire structure. The project team is currently evaluating approaches and conducting preliminary engineering for the various elements of the project. In-situ closure of the Old Waste Calcination Facility at INL (CPP-633) was completed in 1999 but utilized the RCRA process since more significant amounts of contamination were left behind. INL is currently performing ISD closure of the Fuel Reprocessing Facilities Chemical Processing Plant (CPP-601 and 640) under a CERCLA non-time-critical removal action. At SRS, the P-Reactor Area Closure Project has received an Early Action Record of Decision (EAROD) for the ISD concept. Subsequently, P and R Reactor ISD Projects have been accelerated as part of the Savannah River Site ARRA funding.

Because of the relatively limited hands-on operational experience with ISD, the identification of technical challenges and potential solutions should be considered as a starting, but likely incomplete, list. It is certain that further coordination and dialogue with site users, scientists, and technology experts will be required once experience is gained to fully identify emerging needs and solutions.

The DOE decommissioning portfolio includes over 100 large, hardened buildings that may be candidates for ISD. Presently, the EM baseline cost/schedule profile for the seven reactors/processing plants at the Savannah River Site (SRS) assumes and is contingent on the successful Departmental and regulatory acceptance, and safe, costeffective and technically efficient implementation of ISD. Similar ISD assumptions and dependencies currently exist at the Hanford site in Richland, WA. EM-23 will use the portfolio of technical needs identified in this workshop to develop prioritized investment goals that will achieve clear improvements in ISD costs, schedules and/or safety across the DOE Deactivation and Decommissioning (D\&D) program.

To help assure success of the ISD strategy, workshop organizers sought joint input that would achieve the objectives identified in Section 2.2. DOE participants and contractor representatives from Savannah River (SRS), Idaho (INL), and Hanford (RL) - sites having the majority of ISD candidate facilities - provided input to topics in Section 2.3.1. Technical participants are listed in Section 2.3.2. 


\subsubsection{Generalized ISD Technical Challenges}

DOE and contractor personnel knowledgeable in ongoing ISD activities at the three DOE sites were interviewed to identify typical ISD technical challenges. The information collected from the SRS, RL, and INL sites was used to identify the appropriate government, contractor, and vendor expertise required to conduct a successful workshop. From the communication with the sites, the general list of challenges evolved to the contents of Table 1. Detailed issues are presented in Appendix A. 


\section{Table 1. Generalized Technical Challenges for ISD}

\begin{tabular}{|c|c|}
\hline Category & Challenge \\
\hline \multirow[t]{5}{*}{ Characterization } & How do you obtain samples from/perform characterization of inaccessible areas? \\
\hline & $\begin{array}{l}\text { How do you obtain representative samples for analysis of long-lived radionuclides in } \\
\text { the reactor vessel material to establish an accurate source term? }\end{array}$ \\
\hline & $\begin{array}{l}\text { Are modeling assumptions too conservative for the actual physical conditions of the } \\
\text { ISD end state (e.g., long term stability of concrete; soil used for radionuclide transport } \\
\text { predictions when voids are filled with grout)? }\end{array}$ \\
\hline & What types of sensors are needed for long term monitoring of ISD structures? \\
\hline & What type of monitoring can detect precursors that indicate the potential for a release? \\
\hline \multirow[t]{4}{*}{ Stabilization } & $\begin{array}{l}\text { What is the proper formulation for grout to provide the necessary degree of flowability } \\
\text { to sufficiently fill voids yet maintain desired strength (long term stability) to minimize } \\
\text { contaminant mobility? }\end{array}$ \\
\hline & $\begin{array}{l}\text { What is the proper grout formulation to minimize phase separation of water (bleeding) } \\
\text { from the grout during curing? }\end{array}$ \\
\hline & $\begin{array}{l}\text { What method(s) do you use for grout placement to sufficiently fill large voids, vessels, } \\
\text { and inaccessible areas/complex geometries within ALARA constraints? }\end{array}$ \\
\hline & $\begin{array}{l}\text { How do you accomplish isolation/sealing of structure penetrations and "gaps" to } \\
\text { prevent access for water, vermin, vegetation growth, and others? }\end{array}$ \\
\hline \multirow[t]{3}{*}{ Disposal } & How much Transuranic residuals can be left in the structure? \\
\hline & $\begin{array}{l}\text { Can clean fill material (e.g., gravel, soil, debris) be used in place of grout to fill voids; if } \\
\text { so, what method(s) do you use for introducing and compacting it into the ISD facility? }\end{array}$ \\
\hline & $\begin{array}{l}\text { Can contaminated soil be used as fill material; if so, what method(s) do you use for } \\
\text { contamination control during handling and placement, and what method(s) do you use } \\
\text { for introducing and compacting it into the ISD facility? }\end{array}$ \\
\hline \multirow[t]{5}{*}{ Miscellaneous } & $\begin{array}{l}\text { How do you drill through thick concrete and/or steel (possibly from long distances) to } \\
\text { puncture equipment and/or provide access into cubicles? }\end{array}$ \\
\hline & $\begin{array}{l}\text { What alternatives do you consider for lifting heavy items, like cell cover blocks or } \\
\text { equipment, when facility cranes are out of service and retrofitting is not possible? }\end{array}$ \\
\hline & How do you remove the contents of process vessels within ALARA constraints? \\
\hline & How do you deploy bulk adsorbents to sequester process vessel heels? \\
\hline & $\begin{array}{l}\text { What techniques do you use to demolish structure appurtenances that consist of thick } \\
\text { concrete }(>4 \mathrm{ft}) \text { and/or high structures (i.e., } 200 \mathrm{ft}+\text { tall stacks) without damaging the } \\
\text { main structure and compromising the integrity of the entombment barrier? }\end{array}$ \\
\hline
\end{tabular}




\subsubsection{Workshop Participants}

Experienced decommissioning operations personnel from RL, INL and SRS discussed the engineering and technical problems that they face with ISD at their facilities. Scientists and engineers knowledgeable in specific and crosscutting technologies were assembled to identify potential incremental and 'game changing' solutions to those problems and jointly develop project summaries that will lead to successful resolution of the challenges.

Table 2 lists workshop technical participants and their affiliations. A list of technical participants, facilitators, presenters and observers including contact information and expertise, where appropriate, is presented in Appendix B.

\section{Table 2. ISD Workshop Technical Participants}

\begin{tabular}{|l|l|}
\hline \multicolumn{1}{|c|}{ Name } & \multicolumn{1}{c|}{ Affiliation } \\
\hline \hline Bill Austin & Savannah River Nuclear Solutions (SRNS) \\
\hline James Barker & CH2M-WG Idaho (CWI) - Idaho \\
\hline Steve Butterworth & CH2M-WG Idaho (CWI) - Idaho \\
\hline Dares Charoenphol & Department of Energy (DOE) - Headquarters, EM-23 \\
\hline Matt Cole & S.A. Robotics \\
\hline Dan Coyne & CH2M-WG Idaho (CWI) - Idaho \\
\hline Bruce Gillespie & Canberra \\
\hline Ray Hannah & Department of Energy - Savannah River \\
\hline Paula Kirk & Oak Ridge National Laboratory (ORNL) \\
\hline Walt Kubilius & Savannah River Nuclear Solutions (SRNS) \\
\hline Christine Langton & Savannah River National Laboratory (SRNL) \\
\hline Patricia Lee & Savannah River National Laboratory (SRNL) \\
\hline Mark Morton & Polestar \\
\hline Jack Musall & Savannah River Nuclear Solutions (SRNS) \\
\hline Mark Noakes & Oak Ridge National Laboratory (ORNL) \\
\hline Frank Parker & Vanderbilt/CRESP \\
\hline David Roelant & Florida International University \\
\hline Mike Ryan & Independent Consultant \\
\hline Roger Seitz & Savannah River National Laboratory (SRNL) \\
\hline Mark Shaw & DOE-Idaho \\
\hline Dell Simpson & Savannah River Nuclear Solutions (SRNS) \\
\hline Andy Szilagyi & DOE - Headquarters, EM-23 \\
\hline Larry Waggoner & Independent Consultant \\
\hline John Walton & University of Texas, El Paso \\
\hline Lloyd Zinsli & CH2M Hill Plateau Remediation Company, LLC (CPRC) - Hanford \\
\hline
\end{tabular}

\subsubsection{Workshop Agenda}

The workshop began with a tour of SRS and the P Reactor, currently scheduled for ISD closure. The workshop proper opened with introductions from DOE-SRS, DOE-HQ and contractor personnel along with technology perspectives and an overview of DOE's ISD issues and scope; and continued with presentations on ISD challenges from SRS, RL, and INL personnel. The afternoon was wrapped up with an unscheduled presentation on 
reactor closure at RL. Subsequently, a core team of DOE-HQ, SRNL, and PEC personnel met to review and summarize the challenges presented that day and to set up the breakout sessions for the following day. A summary version of the workshop agenda is presented in Table 3.

\section{Table 3. ISD Workshop Agenda}

\begin{tabular}{|c|c|c|}
\hline \multicolumn{3}{|c|}{ Day 1 - December 9, 2008} \\
\hline Time & Topic & Presenter \\
\hline $7: 45$ & Tour Bus Leaves CHR & All \\
\hline $8: 00-9: 00$ & Badging, Orientation & All \\
\hline $9: 00-9: 30$ & SRS Overview & SRS Tours \\
\hline $9: 30-12: 00$ & P Reactor Tour & Chris Bergren/Tony Long (SRNS) \\
\hline $12: 00-1: 00$ & Lunch & \\
\hline $1: 00-1: 15$ & Welcome to Savannah River Site & $\begin{array}{l}\text { Helen Belencan (DOE-SR) } \\
\text { Samit Bhattacharyya (SRNL) } \\
\text { Jyh-Dong Chiou (SRNS) }\end{array}$ \\
\hline $1: 15-1: 30$ & EM-23 Overview & Yvette Collazo (DOE-EM) \\
\hline $1: 30-1: 45$ & Technology Perspectives & Andy Szilagyi (DOE-EM) \\
\hline $1: 45-2: 00$ & ISD Overview & John Gladden (SRNL) \\
\hline $2: 00-2: 15$ & Workshop Objectives/Ground Rules & Rick Martinez (PEC) \\
\hline $2: 15-2: 30$ & Savannah River Needs & Bill Austin (SRNS) \\
\hline $2: 30-2: 45$ & Savannah River Q\&A/Wrap-Up & All \\
\hline $2: 45-3: 00$ & Break & \\
\hline $3: 00-3: 30$ & Hanford ISD Challenges & Lloyd Zinsli/Mark Morton (RL) \\
\hline $3: 30-4: 00$ & Hanford Q\&A & All \\
\hline $4: 00-4: 30$ & Idaho ISD Challenges & Mark Shaw (INL) \\
\hline $4: 30-5: 00$ & Idaho Q\&A & All \\
\hline $5: 00$ & Adjourn & Rick Martinez (PEC) \\
\hline $7: 00-10: 00$ & Structure Challenges & Core Team (EM-23, SRNL, PEC) \\
\hline \multicolumn{3}{|c|}{ Day 2 - December 10, 2008} \\
\hline Time & Topic & Presenter \\
\hline $8: 00-9: 00$ & Overnight Apparitions Discussion & Rick Martinez (PEC) \\
\hline $9: 00-9: 15$ & Breakout Sessions/Session Reports & All/Session Facilitators \\
\hline $4: 15-5: 00$ & Reassemble and Report Out & All \\
\hline $5: 00$ & Adjourn & Martinez/Gladden/Szilagyi \\
\hline
\end{tabular}

Initially, three facilitated breakout sessions were conducted with follow-up presentations to the entire group. These break-out sessions provided direction for subsequent ad hoc sessions that lasted throughout the day. The initial sessions topics and group members are provided in Table 4. The break-out sessions resulted in a number of needs statements (See Appendix C). The workshop was concluded with a wrap-up and summary of the needs statements. 


\section{Table 4. Initial Breakout Session Topics and Groups}

\begin{tabular}{|c|c|c|}
\hline Canyons - Characterization & Modeling/Assumptions and Engineering Considerations & Grout \\
\hline \hline Bruce Gillespie & Frank Parker & Chuck Urland* \\
\hline Dell Simpson & Patricia Lee & Christine Langton \\
\hline Paula Kirk & Rick Martinez* & Mike Ryan \\
\hline Mathew Cole & John Walton & Steve Butterworth \\
\hline Jim Barker & Roger Seitz & Dares Charoenphol \\
\hline Dave Roelant & Mark Morton & Mark Shaw \\
\hline Larry Waggoner & Bill Austin & Ray Hannah \\
\hline Lloyd Zinsli & Erick Reynolds & Jack Musall \\
\hline Mark Noakes & Walt Kubilius & \\
\hline Deborah Shedrow $*$ & Greg Rucker & \\
\hline
\end{tabular}

* Facilitator 
This Page Intentionally Left Blank 


\subsection{WORKSHOP RESULTS}

\subsection{NEEDS STATEMENTS}

Needs identified during the workshop were organized into six basic groups:

- Characterization

- Materials Behavior and Degradation

- Design and Closure

- Monitoring

- Knowledge Management

- Policy Change

The needs statements and associated topics were further developed after conclusion of the workshop. Some needs statements were similar in content and were therefore combined. A summary of the statements, associated topics, and primary authors is listed in Table 5. The full text of the needs statements are presented in Appendix C.

\subsection{WEBCAST PRODUCTS}

A DVD will be distributed to the workshop attendees. The DVD will contain the following information:

- Webcast of the workshop - Portions of the workshop were broadcast live on the internet for viewing by interested parties at DOE-HQ and at the DOE facilities, and include the introductions and facility presentations from SRS, RL and INL, and the close-out summarizing the results of the workshop.

- Workshop PowerPoint presentations.

- List of attendees including contact information, affiliation, and expertise.

- Workshop participant biographies. 
Table 5. ISD Needs Statements Summary

\begin{tabular}{|c|c|c|}
\hline Needs Statement & Purpose & Responsible Author \\
\hline \multicolumn{3}{|l|}{ Characterization } \\
\hline Need 1. In-Tank characterization with isotopic discrimination & $\begin{array}{l}\text { Develop ability to perform in-tank characterization } \\
\text { with isotopic discrimination that would provide timely } \\
\text { data for project planning and decision making. }\end{array}$ & Paula Kirk (ORNL) \\
\hline $\begin{array}{l}\text { Need 2. Field-Deployment systems for difficult contaminants of } \\
\text { concern (COCs) }\end{array}$ & $\begin{array}{l}\text { Develop field instruments that require introduction of a } \\
\text { sample are available for most (COCs). A "game } \\
\text { changing" technology is in remote sensing to identify } \\
\text { and quantify COCs. }\end{array}$ & David Roelant (FIU) \\
\hline \multicolumn{3}{|l|}{ Materials Behavior and Degradation } \\
\hline $\begin{array}{l}\text { Need 3. Degradation rates and parameters for contaminant transport } \\
\text { prediction. }\end{array}$ & $\begin{array}{l}\text { Obtain realistic and technically justifiable estimates of: } \\
\text { 1) degradation/corrosion rates for the various } \\
\text { engineered materials associated with ISD facilities, 2) } \\
\text { sorption coefficients, solubilities, etc. for long-lived } \\
\text { radionuclides in various structural materials and } \\
\text { possible fill materials in order to reduce the } \\
\text { uncertainties in the contaminant transport models. }\end{array}$ & Walt Kubilius (SRNS) \\
\hline Need 4. Long term materials performance studies & $\begin{array}{l}\text { Provide well defined long term (greater than } 500 \text { years) } \\
\text { performance data for Portland cement-based materials. }\end{array}$ & Chuck Urland (PEC) \\
\hline Need 5. Release of activation products from corroded stainless steel & $\begin{array}{l}\text { Define the release mechanism and release rates for } \\
\text { activation products from corroded carbon steel and } \\
\text { stainless steel components. }\end{array}$ & Chuck Urland (PEC) \\
\hline \multicolumn{3}{|l|}{ Design and Closure } \\
\hline Need 6. Flow chart or decision guide for sealing/filling ISD facilities & $\begin{array}{l}\text { Develop guidance for the identification of strategies, } \\
\text { functional requirements and designs for fill and seal of } \\
\text { ISD facilities. }\end{array}$ & Jack Musall (SRNS) \\
\hline Need 7. Seal/fill material "Toolbox" & $\begin{array}{l}\text { Develop material properties and performance } \\
\text { characteristics reference guide for fill materials and } \\
\text { sealants pertinent to ISD requirements. }\end{array}$ & Christine Langton (SRNL) \\
\hline Need 8. Energy and environmentally responsive fill material designs & $\begin{array}{l}\text { Research and identify fill material with } \\
\text { environmentally sustainable contributions and } \\
\text { accounting for LEED criteria, i.e. carbon dioxide } \\
\text { capture material. }\end{array}$ & Christine Langton (SRNL) \\
\hline
\end{tabular}




\begin{tabular}{|l|l|l|}
\hline \multicolumn{1}{|c|}{ Needs Statement } & \multicolumn{1}{|c|}{ Purpose } & \multicolumn{1}{|c|}{ Responsible Author } \\
\hline $\begin{array}{l}\text { Need 14. Developing and testing flowable concrete and grout mixes for } \\
\text { ISD application }\end{array}$ & $\begin{array}{l}\text { Develop highly flowable concrete and grout mixes that } \\
\text { meet the endstate criteria are required for ISD of } \\
\text { reactors, separations, and other large DOE facilities. }\end{array}$ & Christine Langton (SRNL) \\
\hline Monitoring & $\begin{array}{l}\text { Develop a monitoring system that would demonstrate } \\
\text { whether the ISD performance meets program goals and } \\
\text { conforms to project planning predictions. }\end{array}$ & $\begin{array}{l}\text { Mark Morton (Parsons) / Jack } \\
\text { Musall (SRNS) }\end{array}$ \\
\hline Need 9. Design monitoring (including remote sensors) into ISD facility & $\begin{array}{l}\text { Develop a means to upload, organize, and disseminate } \\
\text { information that would be useful for people conducting } \\
\text { risk assessments in support of ISD. }\end{array}$ & Roger Seitz (SRNL) \\
\hline Knowledge Management & $\begin{array}{l}\text { Develop technical reference documents for vetted data } \\
\text { from past ISD related work. Potential Topics: design } \\
\text { concepts, fill materials, other barriers, vetted } \\
\text { physical/chemical properties }\end{array}$ & John Walton (U. of Texas) \\
\hline $\begin{array}{l}\text { Need 10. Measures to improve communication of risk assessment } \\
\text { modeling approaches, data, and lessons learned }\end{array}$ & $\begin{array}{l}\text { Compile data available from existing sample analyses } \\
\text { to establish baseline uncertainty ratios for low-energy, } \\
\text { longer-lived radionuclides. }\end{array}$ & Bruce Gillespie (Canberra) \\
\hline Need 11. Technical resources & Revise DOE Manual DOE M 470.4-6, Nuclear \\
\hline $\begin{array}{l}\text { Need 12. Significant sample analysis is required to establish ratios for } \\
\text { many contaminants of concern (COCs). }\end{array}$ & $\begin{array}{l}\text { Material Control and Accountability, to be more in line } \\
\text { with current D\&D practices. }\end{array}$ & Jim Barker (CWI-Idaho) \\
\hline Policy & $\begin{array}{l}\text { Need 13. DOE Order 470.4-6 Nuclear Material Control and } \\
\text { Accountability }\end{array}$ & \\
\hline
\end{tabular}


This Page Intentionally Left Blank 


\subsection{WORKSHOP FOLLOW-UP}

A review of the needs statements and priorities at the sites resulted in a reassessment of the needs based on the following criteria:

1. Near term needs that can be accomplished by early FY10 to assist in efforts to accelerate footprint reduction.

2. Long term needs that may require further R\&D. These could include further development of needs identified as near term that, when enhanced, could provide a better technology for future ISD actions.

3. Functional requirements for coordination with existing efforts within DOE-EM.

\subsection{NEAR TERM NEEDS}

Several needs represent those that can be accomplished quickly due to either the nature of the need (e.g., it requires the collection of information that can be posted on an existing website) and/or its inclusion to support the accelerated schedules for ISD closure of SRS $\mathrm{P}$ and $\mathrm{R}$ Reactors. In addition, these projects identified some new needs that could help with the acceleration of these schedules.

\subsubsection{SRS P and R Reactor Project Acceleration}

EM funding through the American Recovery and Reinvestment Act (ARRA) is allocated to footprint reduction and acceleration of closure in support of the environmental management risk reduction objectives. As a result, reactor ISD projects at the SRS are underway at an accelerated schedule. P and R Reactor ISD closures are now scheduled to be accomplished by 2011. Near term opportunities to deploy innovative technologies already demonstrated on a laboratory scale are present. Several opportunities exist for pilot scale demonstrations to quantify production results and cost. These near term opportunities must be tailored to address specific project needs and requirements.

Innovative technologies in early development are not candidates for these near term projects because results are still evolving and deployment uncertainties remain high. The early stage technology development focus needs to address the evolving lessons learned and data emerging from the reactor ISD Projects.

Development activities must be sufficiently resilient and flexible to meet project requirements and schedule, and must be coordinated with the project team to ensure current requirements and focuses are maintained. Because of the accelerated ISD schedule for P and R Reactors at SRS, SRNL will be the coordinating organization for all future development activities focused on addressing reactor ISD project technologies.

Table 6 summarizes the application and/or consideration/development of near term innovative technologies in support of reactor ISD projects at SRS. The topics are initial issues for consideration based on emerging project team needs. Table 6 identifies those topics that can be crosswalked to the needs identified in Table 5 and Appendix C. 
Ongoing SRNL activities are identified where appropriate. Additional effort may be required to refine and/or further develop the activity as current efforts may be impacted by schedule. SRNL will review and update this table for validation and relevance in supporting ongoing and future reactor ISD projects.

The timeline in Table 6 focuses specifically on P and R Reactors; however, many of the topics could be further developed in broader scenarios that are not schedule limited. Consequently, these topics should be prioritized in the context of complex-wide facility ISD schedules and funded as longer term technology initiatives. 
Table 6. Technology Development Topics for SRS Reactor ISD Projects

\begin{tabular}{|c|c|c|c|c|}
\hline Topic Area & Need Description & $\begin{array}{c}\text { Development } \\
\text { Phase }\end{array}$ & Near term Application & Out Year Development \\
\hline \multicolumn{5}{|c|}{ Cementitious Barrier Material } \\
\hline $\begin{array}{l}\text { Bulk }^{\text {Fill }}{ }^{\text {I }} \\
\text { Underwater Fill } \\
\text { Normal Fill } \\
\text { Shrink Compensating } \\
\text { Fill } \\
\text { Self-leveling Fill } \\
\text { Non-Alkaline Fill }^{l} \\
\text { Ceramacrete }^{\odot} \\
\text { Second Pass Grout }^{l} \\
\text { Chemical } \\
\text { Other } \\
\text { (Need 8) }\end{array}$ & $\begin{array}{l}\text { Innovative cementitious barrier/fill mix } \\
\text { designs and additives for wet and dry } \\
\text { conditions to enhance flowability and } \\
\text { materials cohesion. Mix designs to } \\
\text { address Bulk Fill, Non-Alkaline Fill } \\
\text { (Reactor Vessel), and Second Pass Grout. }\end{array}$ & $\begin{array}{l}\text { Laboratory, } \\
\text { Bench-scale } \\
\text { testing }^{2}\end{array}$ & $\begin{array}{l}\text { R Reactor Process Room and } \\
\text { Sub Levels large void and reactor } \\
\text { vessel fill ( } \sim 6 \text { months to } 1 \text { year) }\end{array}$ & $\begin{array}{l}\text { P Reactor Process Room and } \\
\text { Sub Levels large void and } \\
\text { reactor vessel fill ( } \sim 18 \text { months } \\
-2 \text { years })\end{array}$ \\
\hline $\begin{array}{l}\text { Compatibility and } \\
\text { Durability } \\
\text { (Need 4) }\end{array}$ & $\begin{array}{l}\text { Material compatibility with broad range } \\
\text { applicability for various metal types, both } \\
\text { for irradiated and non-irradiated conditions } \\
\text { and for wet and dry conditions. }\end{array}$ & Laboratory $^{2}$ & R Reactor Vessel ( $\sim 1$ year) & $\begin{array}{l}\text { P Reactor Process Room and } \\
\text { Sub Levels and Disassembly } \\
\text { Basin }(\sim 18 \text { months }-2 \text { years })\end{array}$ \\
\hline $\begin{array}{l}\text { Characterization of } \\
\text { Freshly Mixed Grout for } \\
\text { Determining Pumping } \\
\text { and Flow Requirements } \\
\text { (Need 14) }\end{array}$ & Improve and characterize rheology & Laboratory & R Reactor Vessel ( $\sim 1$ year) & $\begin{array}{l}\text { P Reactor Process Room and } \\
\text { Sub Levels and Disassembly } \\
\text { Basin }(\sim 18 \text { months }-2 \text { years })\end{array}$ \\
\hline $\begin{array}{l}\text { Concrete Structure } \\
\text { Demolition Using } \\
\text { Explosives }\end{array}$ & $\begin{array}{l}\text { Apply surgical explosive techniques to } \\
\text { demolish concrete structures that cannot be } \\
\text { demolished using conventional } \\
\text { construction methods. }\end{array}$ & $\begin{array}{l}\text { Modeling, } \\
\text { Bench-Scale }\end{array}$ & $\begin{array}{l}\text { R Reactor Stack and } \\
\text { Disassembly Basin above ground } \\
\text { structure ( } \sim 6 \text { months to } 1 \text { year })\end{array}$ & $\begin{array}{l}\text { P Reactor Stack and } \\
\text { Disassembly Basin above } \\
\text { ground structure }(\sim 18 \text { months }- \\
2 \text { years })\end{array}$ \\
\hline
\end{tabular}

\footnotetext{
${ }^{1}$ Conducive for student research.

${ }^{2} \mathrm{SRNL}$ is currently pursuing laboratory test program as part of $\mathrm{P}$ and R Reactor ISD Project.
} 


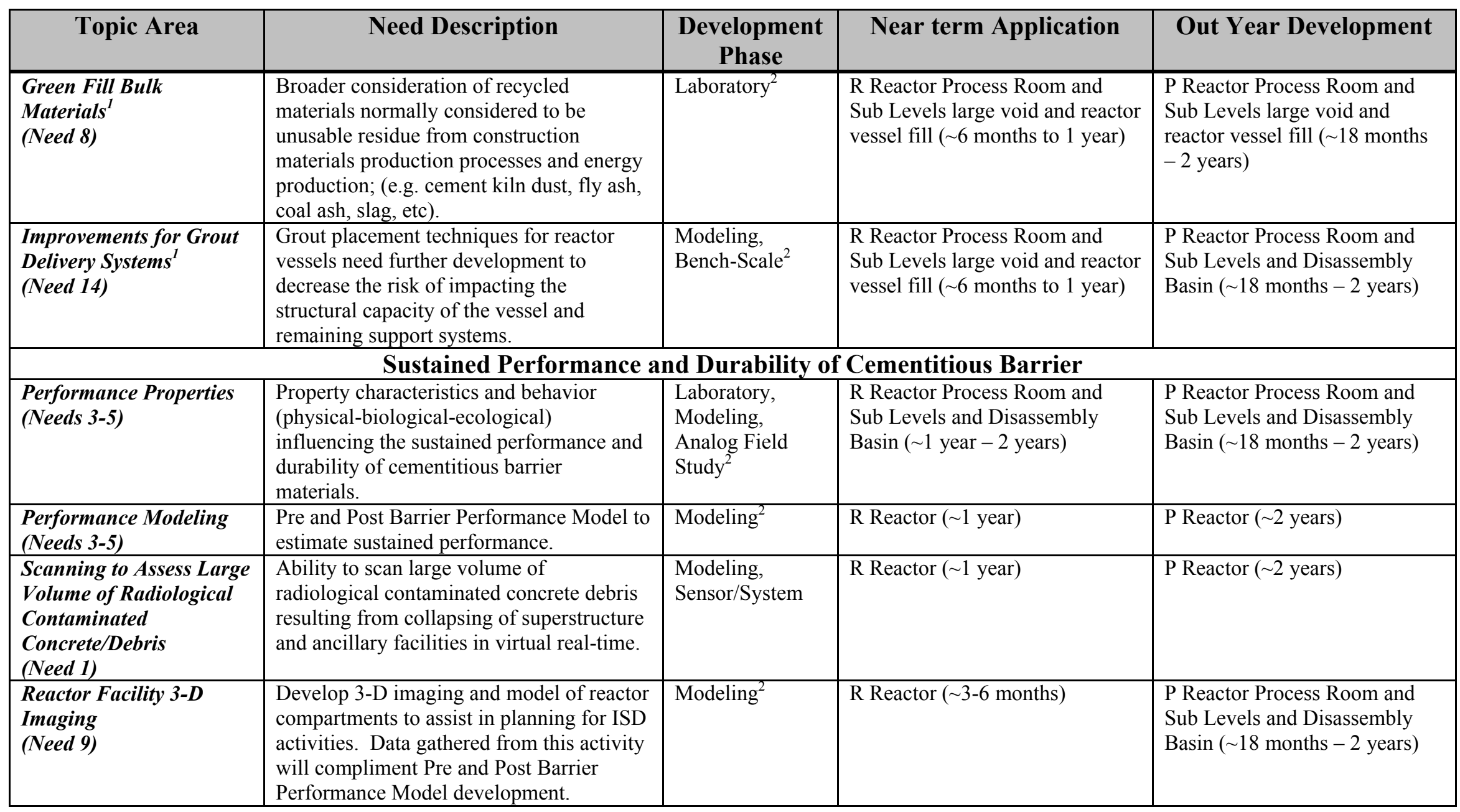

\footnotetext{
${ }^{1}$ Conducive for student research.

${ }^{2}$ SRNL is currently pursuing laboratory test program.
} 


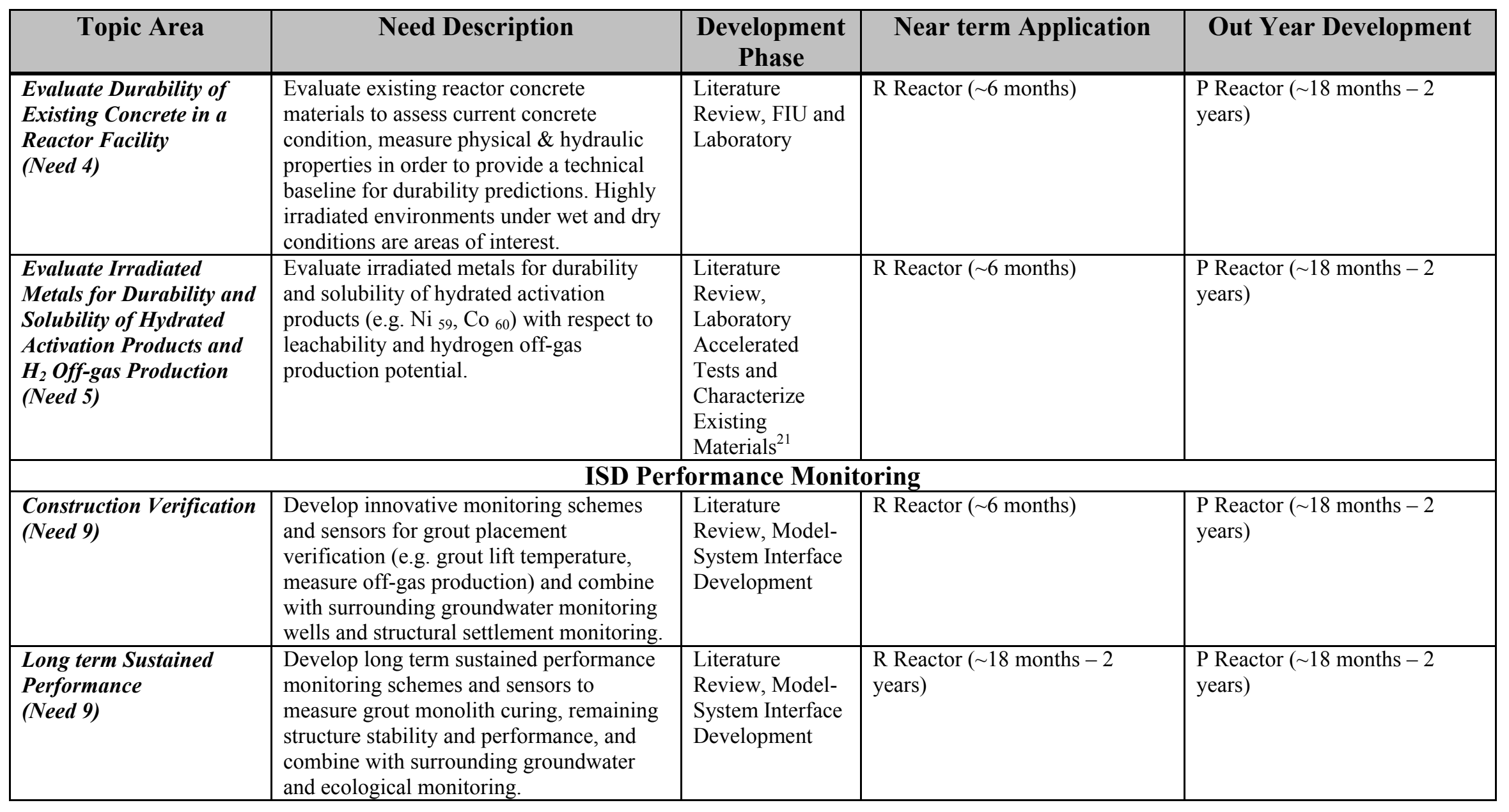

\footnotetext{
${ }^{1}$ SRNL is currently pursuing laboratory test program.
} 


\subsubsection{Knowledge Management}

As identified in Table 5, Needs 10 (Appendix C.10), 11 (Appendix C.11), and 12 (Appendix C.12) fall in the category of knowledge management (KM) and require the placing of existing information in a common accessible location (e.g., a website). There are aspects of the remaining needs that when completed would yield information for dissemination to the ISD community. The aspects of those needs that do not require additional data collection in a laboratory or field can be accomplished quickly using the existing D\&D knowledge management and information technology (KM-IT). In some cases, this may require the development of functional requirements or validation criteria to identify and assemble relevant, validated data for posting.

The D\&D KM-IT is a web based knowledge information tool being developed by Florida International University in collaboration with DOE EM-20, Energy Facility Contractors Group (EFCOG), and the ALARA Centers at Hanford and SRS for the D\&D community. While not specific to ISD, this tool provides a gateway for the D\&D community to share information and experience.

Functional requirements for the type, level, validation, and coordination of information for the sharing of ISD information need to be developed for the authors of the D\&D KM-IT. An ISD-specific area should be added to the D\&D KM-IT website and used as a vehicle to maintain and disseminate information for ISD projects. EM-23 should continue sponsorship of this ISD-specific area by providing support to FIU and to key SRS, INL, and RL personnel

\subsection{OUT YEAR R\&D NEEDS}

The topics identified in Table 6 for support of the $\mathrm{P}$ and $\mathrm{R}$ reactor projects at SRS identify near term items that are in most cases being developed in real time given the $\mathrm{P}$ and $\mathrm{R}$ reactor accelerated schedules. Given the availability of more time and funding, many of these items require refinement for future use for ISD of reactors and other facilities (e.g., Canyons). In addition to the long term studies that may be required to adequately address these topics, lessons learned during the early stages of development execution for $\mathrm{P}$ and $\mathrm{R}$ Reactors will help identify areas requiring further development.

Workshop Needs 1 (Appendix C.1), 2 (Appendix C.2), and 9 (Appendix C.9) identify the need for methods to perform in situ measurement of contaminants and/or performance characteristics for ISD. Need 1 identifies in-tank characterization with isotopic discrimination that would provide timely data for project planning and decision making, highlighting the reduction in cost and schedule through elimination of sample retrieval and measurement. Need 2 identifies the need for field instruments and remote sensing in situ measurements that would yield a similar cost saving and improve worker safety risk. Need 9 identifies the need for a series of robust sensors distributed throughout the facility that could provide time dependent information about performance, thus helping to validate the modeling assumptions and structural performance. 


\subsection{FUNCTIONAL REQUIREMENTS FOR RELATED EFFORTS}

Ongoing efforts outside of EM-23 also apply to ISD and will require increased interaction. This includes efforts for the Cementitious Barriers Partnership Project, (CBP) (EM-21), broader modeling efforts such as those supported by EM-21 and EM-11, and long term/performance modeling efforts supported by EM-22. The development of functional requirements would allow ISD needs to be addressed as a part of these efforts, where appropriate, and could be cost effective because it could eliminate the duplication of effort.

\subsubsection{Cementitious Barriers Partnership Project}

Need 4 identifies the need for well defined long term (greater than 500 years) performance data for Portland cement-based materials. The goal of the CBP is to develop a reasonable and credible set of tools to predict the structural, hydraulic and chemical performance of cement barriers used in nuclear applications over extended time frames (e.g., $>100$ years for operating facilities and $>1000$ years for waste management facilities). Need 4 corresponds to the CBP's goal to demonstrate, develop or improve experimental data to verify conceptual models and provide model parameterization for a set of reference cases.

\subsubsection{Community of Practice}

The Community of Practice (COP), supported by EM-21 and EM-11, is working to:

- reduce regulatory and technical risks related to performance assessment (PA) implementation,

- foster continuous improvement in the quality, credibility, consistency, and efficiency of DOE's PA and risk-based decision-making,

- maintain enduring performance and risk assessment capability and knowledge base for the DOE Complex, and

- facilitate the exchange of PA information both content and methods.

These COP objectives are relevant to several needs concerning knowledge management, which were identified at the ISD workshop. The COP efforts should be leveraged for use by ISD projects.

\subsubsection{Long Term Monitoring Efforts}

The ISD closure strategy entails the permanent entombment of contaminated material and structures. Ensuring the contaminants remain contained within the entombment over exceptionally long time periods necessitates effective, robust, and cost effective methods for monitoring the integrity of the structure for centuries.

The 2009 DOE-EM Long Term Monitoring Technical Forum sponsored by EM-22 was held to identify technical needs that would advance the paradigm of long term monitoring 
(LTM) associated with legacy waste sites; the technical needs will focus on the areas of LTM tools, systems and information management. The forum breakout groups focused on:

- development/use of innovative or novel LTM information management strategies and techniques addressing parameters such as data issues, statistics, modeling, visualization, linkage to objectives, and state of the art data management techniques;

- identification and development of innovative LTM systems addressing the framework for interactive parameters such as infrastructure, sensors, diagnostic features, field screening tools, state of the art characterization monitoring systems/concepts, and ecosystem approaches to site conditions and evolution; and

- integration and improvement of LTM performance measurement and monitoring tools that deal with parameters such as ecosystems, boundary conditions, geophysics, remote sensing, biomarkers, ecological indicators and other types of data used in LTM configurations.

These topics are relevant to ISD, particularly the development needs associated with characterization and performance modeling (Workshop Needs 1, 2, and 9). EM-23 would benefit by exploiting this resource and sponsoring a forum focused on monitoring issues associated with ISD closure. 


\subsection{SUMMARY AND RECOMMENDATIONS}

The ISD Technical Workshop and follow-up activities yielded 14 technology development needs statements (Table 5 and Appendix C). The accelerated schedules for ISD of the $\mathrm{P}$ and R Reactors at SRS yielded needs for those projects (Table 6). In all cases, the topics are those that could apply to ISD actions throughout the DOE complex.

\subsection{PATH FORWARD}

SRNL personnel will continue to work with the SRS P and R Reactor closure project teams to identify new technology needs and address near term issues as they arise. Once the remedial action is in-place (i.e., Reactor ISD) additional, regular meetings (at least annually) should be held for operations and laboratory personnel from each of the sites planning ISD closures to evaluate performance and potential modifications.

Many of the R\&D projects listed in Table 6 are ongoing and/or have been initiated due to the acceleration of the $\mathrm{P}$ and $\mathrm{R}$ Reactor projects. It is recommended that those projects be funded at SRS to preserve the work that has been performed to date and that the lessons learned be documented for out year refinement where appropriate. In some cases this may be a matter of providing funding to document the approach at the HQ level for use throughout the complex. In others it may be necessary to perform laboratory and/or field analysis to evaluate assumptions made in those projects and/or adjust the approach for more generic complex-wide use. Many of the topics are conducive to student research that can be conducted at universities via fellowships and/or using summer interns as footnoted in Table 6 . However, there are situations where the R\&D required to meet the need should be funded based on solicited research proposals across the complex and industry.

An ISD-specific area should be added to the D\&D KM-IT website and used as a vehicle to maintain and disseminate information for ISD projects. EM-23 should continue sponsorship of this ISD-specific area by providing support to FIU and to key SRS, INL, and RL personnel

\subsection{RECOMMENDATIONS}

The results of the workshop and of subsequent analyses based on the acceleration of the $\mathrm{P}$ and R Reactor ISD projects suggests that EM-23 should prioritize and pursue (either through a request for proposal or task change request) the following specific technology development and deployment actions:

1. Develop and demonstrate new and alternative fill materials

a. Ceramicrete testing of "non-alkaline fill" for reactor vessel ISD

b. Highly flowable concrete and grout mixtures

c. Alternative "Green" fill materials 
2. Select (and/or develop) and deploy a suite of sensors to verify the performance of near-term ISD projects (subsidence, stress/strain, and fractures)

3. Develop an ISD-specific performance model

a. Develop ISD-specific conceptual site model

b. Incorporate performance verification dataset from P\&R ISD

c. Perform sensitivity analyses to identify suite of key parameters

d. Identify data quality objectives for key parameters

4. Define and quantify the degradation rates and release mechanisms for:

a. Concrete structures,

b. Activation products from steel, and

c. Fill materials

5. Develop and deploy state of the art characterization instrumentation

a. Difficult to sample locations (tanks and sumps)

b. Difficult to measure contaminants (long-lived, low-energy, and SNM)

c. Develop indicator contaminant or isotopic ratios

\subsection{TASK JUSTIFICATIONS}

\subsubsection{Reactor ISD use of Non-Alkaline Fill (Ceramicrete)}

Also as a response to Need \#14, work is needed to demonstrate chemically bonded phosphate ceramic material as a viable option for filling SRS reactor, particularly for reactor vessels). Argonne National Laboratory has patented several materials/applications for chemically bonded phosphate ceramic cements (e.g., Ceramicrete). They are acidbase cements (mixture of $\mathrm{MgO}$ and $\mathrm{KH} 2 \mathrm{PO} 4+\mathrm{H} 2 \mathrm{O}$ which results in a magnesium phosphate hydrate matrix). The $\mathrm{pH}$ range for this cement is 4-8, i.e., good for systems with Al metal. Solidifying reactor vessels and other reactor components that have high Al metal contents remains an open issue due to contact with high $\mathrm{pH}$ cement-grout formulations and the potential off-gas hydrogen production. The lower $\mathrm{pH}$ range provides a means to control off-gas hydrogen production due to $\mathrm{Al}$ metal corrosion with a higher $\mathrm{pH}$ mixture.

Collaboration between SRNL and Argonne National Laboratory to develop the lower $\mathrm{pH}$ cement-grout formulation is recommended. Much of this research and field work can be accomplished quickly and economically using students and/or summer interns. This effort has the high potential as a near-term deployment for Reactor ISD projects across the Complex.

\subsubsection{Highly Flowable Concrete and Grout Mixtures}

As identified in Need \#14, flowable concrete and grout mixtures are required for ISD of reactor, separation, and other DOE facilities with radioactive and hazardous 
contamination. Hundreds of thousands of cubic meters of fill material are required for ISD of DOE facilities.

The above and below grade structures that make up reactor, separation, and other large contaminated DOE facilities need to be physically stabilized to prevent collapse or creation of a "bath tub" effect and chemically stabilize contaminants. Flowable fill materials are needed to reduce labor costs and to enhance ALARA. A menu of demonstrated flowable mix designs will facilitate designs of ISD activities, reduce costs and risks, and accelerate implementation.

The objective of this task is to apply existing concrete technology for flowable and self consolidating concrete to designing fills with low hydration heat, zero bleed / segregation, and enhanced contaminant stabilization properties for ISD applications. The fill materials need to be tailored for underwater, pre-placed aggregate/debris, light and heavy weight, and bulk fill applications.

\subsection{3 “Green" Fill Material}

As identified in Need \#8, the high volume of infill and back fill materials that will be used for the 100,000's of cubic meters of material used in the DOE ISD projects warrants Leadership in Energy and Environmental Design (LEED) consideration. DOE is heavily invested in LEED technology to reduce carbon emissions and the use of fossil fuels.

The technical approach consists of identifying a base case(s) for fill materials that meets the requirements for bulk fill and using standard LEED practices for:

- Assessing the carbon emissions and fossil fuels consumption involved in producing these materials

- Identifying alternatives or options for reducing the fossil fuel consumption and carbon emissions involved in producing these materials.

The U.S. Green Building Council (USGBC) LEED practices will be applied where applicable. If they are inadequate for capturing the full carbon emissions, fossil fuel consumption, innovative approaches need to be developed.

\subsubsection{Reactor ISD Performance Verification}

Need \#9 focuses on monitoring system design for ISD facilities, which includes construction verification activities during application of the remedial action. Construction verification normally encompasses field data acquisition for basic technical parameters (e.g., cementitious material temperature, lift thickness, injection pressure, etc.). Construction verification data sets are the initial technical baseline from which system performance emerges until sustained performance is achieved. The initial technical baseline is not limited to the remedial action application (i.e., ISD), but also the initial effect on the adjacent physiographic setting. This adjacent physiographic setting 
effect is often overlooked, but is important input to validating and/or adjusting overall ISD system performance predictions.

The SRS Area Completion Project (ACP) is currently undertaking the first of its kind, large-scale ISD of a hardened facility (i.e., reactor building complex [RBC]) at SRS. Recent agreements with U.S. Environmental Protection Agency (USEPA) and South Carolina Department of Health and Environmental Control (SCDHEC) and public acceptance have paved the way for this closure approach.

Two RBCs, P Area and R Area, respectively, are slated to undergo a large-scale in-situ decommissioning process. The R Reactor Building Complex (R-RBC) - Disassembly Basin is the initial facility component to be filled with grout under ISD. ISD will encompass the placement of grout throughout the sublevels of the RBCs. In addition, the disassembly basin and reactor vessel at each $\mathrm{RBC}$ will be grouted and capped. The type of grout that is to be placed in the RBCs is currently being addressed by SRNL personnel based on specific design criteria. It is estimated that upwards of $130,000 \mathrm{cu}$ yd of material will be placed within the structures. This quantity of material will add significant loading to the structure and onto the surrounding soil.

Portions of the R-RBC are in the shallow groundwater, which is approximately $9 \mathrm{ft}$ below the surface. It is estimated upwards of $31,000 \mathrm{cu}$ yd of grout, which has an estimated density 2.5 times that of water will be placed in the Disassembly Basin. The effects resulting from significant increased loading due to the large quantity of grout material added to the P- and R-RBC on the surrounding soil structure and water table are unknown and therefore can only be modeled using gross assumptions.

The effects of placing a large quantity of material within the structures and the current physiographic setting are unknown. Monitoring of the reactor structures and groundwater before, during, and after ISD activities for both RBCs would provide the data necessary to build and verify the refined performance model. This monitoring approach should involve measurement of the following physical properties:

1. Vertical settlement/displacement - Install and monitor, at a minimum, at the expansion joint along the disassembly basin and process areas

2. Structure for subsisdence - Install and collect laser monitoring of elevations of the disassembly basin and main reactor process building

3. Effects on the shallow groundwater elevation - Instrument nearby shallow groundwater wells with transducers to measure

The data collected will be used to establish baseline conditions and to identify facility settlement and adverse impacts to groundwater due to the increased loading from grout placement in the facility. The information gathered from these activities supplies a key element in predicting the longevity of the Reactor ISD activities.

Need \#9 identified that a monitoring system should be developed that would demonstrate whether the ISD performance meets program goals and conforms to project planning 
predictions. The early design and implementation of a comprehensive monitoring scheme for an ISD structure is seen as a benefit in the near term (20 to $50 \mathrm{y}$ ) and for the long term $(>100 \mathrm{y})$ to demonstrate that the ISD design is functioning as planned to isolate the source term. A series of robust sensors distributed throughout the facility could provide time dependent information about performance, thus helping to validate the modeling assumptions and structural performance.

\subsubsection{Reactor ISD Performance Model}

Need \#9 and Need \# 10 highlight the monitoring system design and the ability to improve risk assessment communication. ISD-Specific performance models are required to estimate sustained performance and are the means to integrate the wide-range data set to validate and/or adjust performance predictions. These models can provide the key elements for predicting the longevity and risk reduction of the Reactor ISD activities.

Understanding cementitious material (i.e., concrete and grout) curing process is an important parameter to maintaining sustained performance for Reactor ISD. The curing of concrete is an exothermic process. During the setting process, most of the heat of hydration is released as a spike commencing several hours after mixing. The duration of this spike is approximately thirty hours. Thereafter energy is released at a low rate for a long period, months or even years. If a large volume of concrete is poured quickly, the heat of hydration can result in elevated interior temperatures which degrade the integrity of the concrete. The simplest way to avoid excessive temperatures is to pour the concrete in stages, allowing most of the energy released in the initial heat of hydration spike to be conducted to the boundaries before the next pour.

The encapsulation of decommissioned nuclear facilities with cementitious material (i.e., concrete and grout) is a process in which the heat of hydration will possibly limit the rate that the concrete can be poured. Thermal modeling of the pouring process is the appropriate method for determining optimum pour schedules. Because of the delay after pouring in the release of the heat of hydration, the peak concrete temperatures will occur after a pour is completed. Application of embedded thermocouples provides a cursory view of the thermal horizon build-up during the initial curing phase, which is related to fresh material properties and characteristics.

All of the energy released during curing is ultimately dissipated by thermal conduction to the boundaries and ultimately to the environment. A multi-dimensional model that includes the seasonal temperature variation is therefore necessary for general application.

Development of these models requires structural and seasonal input. In addition to the construction verification task identified below, existing industry models can be used for certain baseline estimates.

These models can be learned and executed using summer interns and students at universities. The performance verification task can provide the data necessary for further 
refinement from the baseline for these models and the multidimensional site-specific models if needed.

For R Reactor, existing models used for pouring concrete in a uniform waste facility has been adapted for use due to schedule limitations. The complexity of the $\mathrm{P}$ and R Reactor Building Complexes (RBCs) require a refined model that considers the appropriate physical properties. Development of this model for use and R and P Reactor could provide the baseline for the remaining reactor facilities and Canyons and SRS and other DOE facilities.

Sensitivity analyses using the developed performance models should be performed to identify the key parameters that need to be monitored. The data quality objectives (DQOs) for these monitoring instruments can then be identified. Development of these DQOs would focus future technology development by establishing the baseline requirements for the parameters to be monitored and the sensor design criteria.

\subsubsection{Degradation and Release Mechanisms for Concrete Structures and Fill Material}

As identified in Needs \#3 and 4, the ISD end state is a viable option for disposition of contaminated robust concrete structures. The current practice for the preparation of these structures for ISD is to fill them with grout to immobilize residual contaminants. The basis for this costly practice has come under question. A better understanding of the long term performance of the concrete materials (in terms of providing both containment and stability) may enable removal of conservatisms from modeling assumptions that drive costly ISD implementation approaches.

The objective of this task is to obtain realistic and technically justifiable estimates of 1) degradation rates for the various engineered materials associated with ISD facilities, and 2) sorption coefficients, solubilities, etc. for long-lived radionuclides in various structural materials and possible fill materials. Better estimates of these parameters will greatly reduce the uncertainties of risk predictions in the contaminant transport models

\subsubsection{Release Rates for Activation Products from Steel}

As identified in Need \#5, a better understanding of the release mechanism for activation products from corroded carbon and stainless steel is needed to quantify the source term used in release calculations for ISD projects. More accurate predictions of the amount that will be released and the time frame for the release may enable a reduction in the conservatism in modeling assumptions thus allowing implementation of more streamlined and cost-effective "engineered" measures.

The objective of this task is to conduct material science studies on activated or surrogate activated carbon steel and stainless steel specimens to provide a better understanding of the manner and timing in which activation products are released from these materials. 
Simulated material studies, similar to the work conducted by the U.S. NRC to support the licensing of High Integrity Containers for LLW burial, should be conducted to provide the necessary data.

\subsubsection{Instrumentation for Difficult to Sample and Measure Contaminants}

As identified in Needs $\# 1$ and 2, the ability to perform in field characterization for difficult to sample and measure contaminants of concern would provide timely data for project planning and decision making.

For difficult to sample contaminants, the objective of this task is to use an integrated systems approach to develop and demonstrate field deployable in-situ characterization technologies that can be deployed in tanks or sumps to determine total radiation levels and determine the specific isotopic content.

For difficult to measure contaminants, the objective of this task is to provide remote sensor capability for:

- Low-energy, longer-lived radionuclides

- $\mathrm{SNM}$ in-situ (inside equipment, inside pipes embedded in walls and floors)

- $\mathrm{SNM}$ in high radiation environments

- RCRA metals (e.g., Be)

These technical assessments should include how DOE sites are currently handling sampling, indicator species, and isotope ratios for quantification of these contaminants. 


\subsection{ACKNOWLEDGEMENTS}

This workshop was supported by the U.S. Department of Energy Department of Energy's (DOE) Office of Environmental Management (EM), Office of Engineering and Technology (EM-20) - Office of Deactivation and Decommissioning and Facility Engineering (EM-23). The authors of this document would like to thank Andrew Szilagyi and Dares Charoenphol (DOE, HQ, EM-23) for their support and contribution to this report. In addition, the authors would like to thank the workshop participants for their contribution to the workshop and the contents of this report. Special thanks to PEC personnel who helped to plan, facilitated and participated in the workshop and development of this report. The authors and EM-23 greatly appreciate the support from the field offices and contractor personnel from Hanford and Idaho. 


\section{Appendix A. ISD Technical Challenges Detailed Issues}

\begin{tabular}{|c|c|c|}
\hline Topic & Sub-Topic & Challenge-Problem \\
\hline \multirow{3}{*}{$\begin{array}{l}\text { Risk drivers, } \\
\text { methodologies } \\
\text { and mitigation }\end{array}$} & Modeling & $\begin{array}{l}\text { Appropriate models being used? } \\
\text { Appropriate input parameters (e.g. how to account for binding of } \\
\text { activation products, such as Ni-63 with steel in the Reactor } \\
\text { internals) }\end{array}$ \\
\hline & $\begin{array}{l}\text { Performance of grout } \\
\text { and reinforced concrete } \\
\text { as barriers }\end{array}$ & $\begin{array}{l}\text { Overly conservative modeling, as soil, currently being used for } \\
\text { radionuclide transport performance }\end{array}$ \\
\hline & Transuranics residuals & How much can be left in canyons? \\
\hline \multirow{11}{*}{$\begin{array}{l}\text { 2. Grout } \\
\text { Formulation and } \\
\text { Placement }\end{array}$} & Formulation & $\begin{array}{l}\text { Grout and/or controlled density fill (CDF) formulations to provide } \\
\text { proper degree of flowability to sufficiently fill voids and maintain } \\
\text { desired strength while minimizing contaminant mobility. }\end{array}$ \\
\hline & Structural mechanics & $\begin{array}{l}\text { Long term stability of material of containment system }(500 \mathrm{yr} \\
\text { containment correct assumption?, rate of degradation beyond } 500 \\
\text { yrs) }\end{array}$ \\
\hline & Reactions & Structural degradation of steel barriers \\
\hline & \multirow{8}{*}{ Placement } & Batch processing vs. continuous pour \\
\hline & & $\begin{array}{l}\text { P Reactor Tank - Grout placement method to fill and cap RV with } \\
\text { grout that minimizes infiltration }\end{array}$ \\
\hline & & $\begin{array}{l}\text { P Reactor Tank - Grout placement method to minimize personnel } \\
\text { exposure }\end{array}$ \\
\hline & & $\begin{array}{l}\text { P Reactor - Grout placement method to below grade levels and } \\
\text { demineralizer cells }\end{array}$ \\
\hline & & $\begin{array}{l}\text { U-Plant - Grout placement into the cell drain header w/ tremie } \\
\text { pipes (up to } 600 \mathrm{ft} \text { ) into a } 24 \text { inch diameter pipe over } 28 \mathrm{ft} \text { below } \\
\text { the deck -- accomplish within ALARA principles }\end{array}$ \\
\hline & & PUREX Railroad Tunnels \\
\hline & & B-Plant HEPA Filter Vaults \\
\hline & & $\begin{array}{l}\text { Placement ( } \& \text { formulation) of grout to minimize phase separation } \\
\text { of water (bleeding) from the grout resulting in voids and migration } \\
\text { of contaminants }\end{array}$ \\
\hline \multirow{5}{*}{ 3. Characterization } & & Sampling of inaccessible areas (see Remote Technology) \\
\hline & Inaccessible Areas & $\begin{array}{l}\text { PUREX Railroad Tunnels - High radiation, difficult entry, } \\
\text { difficult pathways, and ugly sources - How to get sufficient data } \\
\text { from equipment in the rail cars and sources. }\end{array}$ \\
\hline & \multirow{3}{*}{ Monitors-Sensors } & Detection of precursors that indicate potential for release. \\
\hline & & $\begin{array}{l}\text { Detection limits-sufficient detectors to measure contamination } \\
\text { (i.e., activation products) at the point of compliance (i.e. nearest } \\
\text { well) considering the low concentrations after release is diluted by } \\
\text { groundwater. }\end{array}$ \\
\hline & & Detect activity in remote areas \\
\hline \multirow{2}{*}{ 4. Metallurgy } & $\begin{array}{l}\text { Corrosion of steel and } \\
\text { concrete structures. }\end{array}$ & $\begin{array}{l}\text { Unknown effects of interaction between activation products within } \\
\text { steel and concrete }\end{array}$ \\
\hline & Reactor Vessel samples & $\begin{array}{l}\text { Obtain samples for analysis of long-lived radionuclides in the } \\
\text { vessel material to establish accurate source term. }\end{array}$ \\
\hline \multirow{3}{*}{ 5. Isolation-Sealing } & $\begin{array}{l}\text { Below Grade } \\
\text { Penetrations } \\
\end{array}$ & $\begin{array}{l}\text { P Reactor - Prevention of water infiltration for the duration } \\
\text { required }\end{array}$ \\
\hline & Above Grade Structure & $\begin{array}{l}\text { P Reactor - Need to seal huge remaining gap to prevent access to } \\
\text { the superstructure - water, vermin, vegetation growth, others? }\end{array}$ \\
\hline & $\begin{array}{l}\text { Below Grade Structure } \\
\text { Integrity }\end{array}$ & Avoid collapsing of subsurface walls during demolition. \\
\hline
\end{tabular}




\begin{tabular}{|l|l|l|}
\hline \multicolumn{1}{|c|}{ Topic } & \multicolumn{1}{|c|}{ Sub-Topic } & \multicolumn{1}{c|}{ Challenge-Problem } \\
\hline \multirow{4}{*}{$\begin{array}{l}\text { 6emote } \\
\text { Technology }\end{array}$} & Drilling & $\begin{array}{l}\text { P Reactor - Drilling through 5 feet of concrete and reactor walls } \\
\text { for grout feed and void venting }\end{array}$ \\
\cline { 2 - 3 } & Sampling & $\begin{array}{l}\text { U-Plant - remote puncturing of equipment to prevent floating } \\
\text { when cells/vaults are grouted. }\end{array}$ \\
\cline { 2 - 3 } & Grout hose placement & Sampling Remote Locations \\
\cline { 2 - 3 } & Process Vessel Heels & $\begin{array}{l}\text { U-Plant - Remote deployment of bulk absorbents OR remote } \\
\text { contents removal }\end{array}$ \\
\hline \multirow{4}{*}{$\begin{array}{l}\text { Use of inert fill } \\
\text { material in place } \\
\text { of grout }\end{array}$} & $\begin{array}{l}\text { Use of clean fill } \\
\text { material (gravel, soil, } \\
\text { demo debris) }\end{array}$ & $\begin{array}{l}\text { Approval to use in place of grout; method of introducing \& } \\
\text { compacting into the ISD facility }\end{array}$ \\
\cline { 2 - 3 } & $\begin{array}{l}\text { Use of contaminated } \\
\text { soil as fill material }\end{array}$ & $\begin{array}{l}\text { Contamination control during handling \& placement; method of } \\
\text { introducing \& compacting into the ISD facility; DOE O 435.1 } \\
\text { issues }\end{array}$ \\
\hline \multirow{3}{*}{ 8. Miscellaneous } & Equipment Handling & $\begin{array}{l}\text { U-Plant - Lifting alternatives (for cell cover blocks or equipment) } \\
\text { when facility cranes are out of service (and retrofitting is not } \\
\text { possible). }\end{array}$ \\
\cline { 2 - 3 } & Demolition Techniques & U-Plant - For thick ( $>4 \mathrm{ft}$ concrete \\
\cline { 2 - 3 } & U-Plant/P Reactor - For 200 ft + stacks \\
\hline
\end{tabular}




\section{Appendix B. ISD Workshop Attendee Contact Information}

\section{Table B1. Technical Participants}

\begin{tabular}{|c|c|c|c|c|c|c|c|c|c|c|c|}
\hline \multirow[b]{2}{*}{ Name } & \multirow[b]{2}{*}{ Affiliation } & \multirow[b]{2}{*}{ Email } & \multicolumn{9}{|c|}{ Expertise } \\
\hline & & & 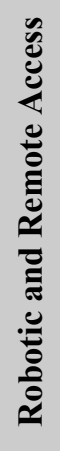 & 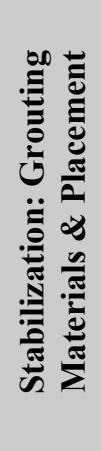 & 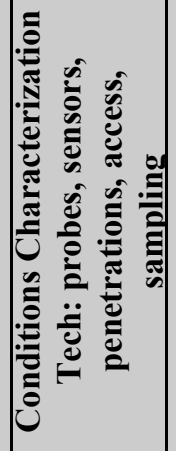 & 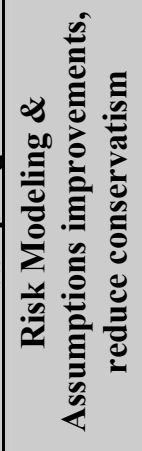 & 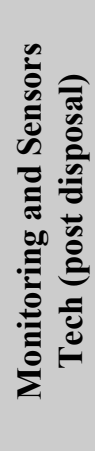 & 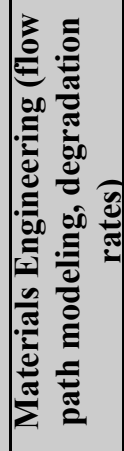 & 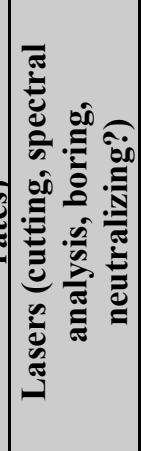 & 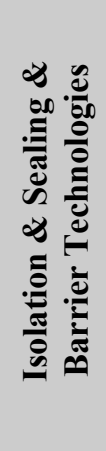 & 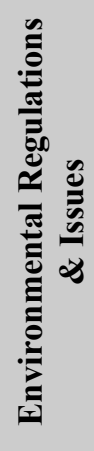 \\
\hline Bill Austin & SRNS & william.austin@srs.gov & & & & & & & & & \\
\hline James Barker & CWI - Idaho & james.barker@icp.doe.gov & & & & & & & & & \\
\hline Steve Butterworth & CWI - Idaho & steven.butterworth@icp.doe.gov & & $\mathbf{X}$ & & & & & & & \\
\hline Dares Charoenphol & DOE-HQ & Dares.Charoenphol@hq.doe.gov & & & & & $\mathbf{X}$ & & & & \\
\hline Matt Cole & S.A. Robotics & matt@sarobotics.com & $\mathbf{X}$ & & & & & & & & \\
\hline Dan Coyne & CWI - Idaho & daniel.coyne@icp.doe.gov & & $\mathbf{X}$ & & & & & & & \\
\hline Bruce Gillespie & CANBERRA & bgillespie@canberra.com & & & $\mathbf{X}$ & & & & & & \\
\hline Ray Hannah & DOE - SR & george.hannah@srs.gov & & & & $\mathbf{X}$ & & & & & $\mathbf{X}$ \\
\hline Paula Kirk & ORNL & kirkpg@ornl.gov & & & & & $\mathbf{X}$ & & & & \\
\hline Walt Kubilius & SRNS & walt.kubilius@srs.gov & & & & $\mathbf{X}$ & & & & & \\
\hline Christine Langton & SRNL & christine.langton@srnl.doe.gov & & & $\mathbf{X}$ & $\mathbf{X}$ & $\mathbf{X}$ & & & & \\
\hline Patricia Lee & SRNL & patricia.lee@srnl.doe.gov & & & & & $\mathbf{X}$ & & & & $\mathbf{X}$ \\
\hline Mark Morton & Polestar & mark.morton@worleyparsons.com & & & & & & & & $\mathbf{X}$ & \\
\hline Jack Musall & SRNS & john.musall@srs.gov & & & & & & $\mathbf{X}$ & & & \\
\hline Mark Noakes & ORNL & noakesmw@ornl.gov & $\mathbf{X}$ & & & & & & & & \\
\hline Frank Parker & Vanderbilt/CRESP & frankl.parker@vanderbilt.edu & & $\mathbf{X}$ & & & & & & & \\
\hline David Roelant & FL Int'1 University & roelantd@fiu.educ & & $\mathbf{X}$ & & & & & & & \\
\hline Mike Ryan & Ind. Contractor & mryan3698@charter.net & & $\mathbf{X}$ & & & & & & & \\
\hline
\end{tabular}




\begin{tabular}{|c|c|c|c|c|c|c|c|c|c|c|c|}
\hline \multirow[b]{2}{*}{ Name } & \multirow[b]{2}{*}{ Affiliation } & \multirow[b]{2}{*}{ Email } & \multicolumn{9}{|c|}{ Expertise } \\
\hline & & & 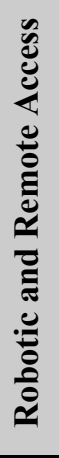 & 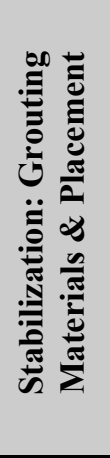 & 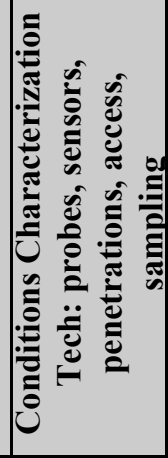 & 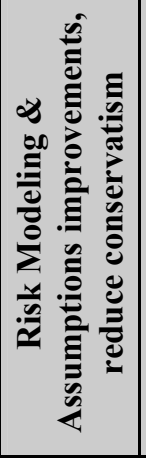 & 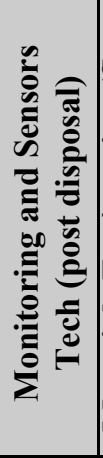 & 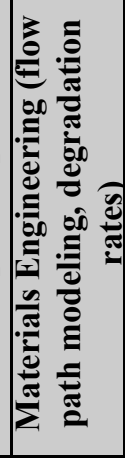 & 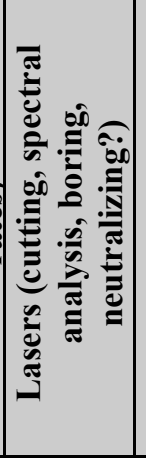 & 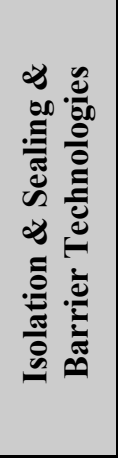 & 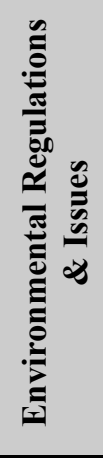 \\
\hline Roger Seitz & SRNL & roger.seitz@srnl.doe.gov & & & & $\overline{\mathbf{X}}$ & & & & & $\overline{\mathbf{X}}$ \\
\hline Mark Shaw & DOE-ID & shawrm@id.doe.gov & & $\mathbf{X}$ & & & & & & & $\mathbf{X}$ \\
\hline Dell Simpson & SRNS & wooten.simpson@srs.gov & & $\mathbf{X}$ & & & & & & & \\
\hline Andrew Szilagyi & DOE-HQ & Andrew.Szilagyi@em.doe.gov & & & & & & & & & \\
\hline Larry Waggoner & Ind. Contractor & 1waggoner@wavecable.com & & & & & & & & $\mathbf{X}$ & \\
\hline John Walton & University of Texas & walton@utep.edu & & $\mathbf{X}$ & & & & & & & \\
\hline Lloyd Zinsli & Hanford CPRC & Lloyd C Zinsli@rl.gov & & $\mathbf{X}$ & & & & & & & \\
\hline
\end{tabular}


Table B2. Presenters, Facilitators and Observers

\begin{tabular}{|c|c|c|c|c|c|c|c|c|c|c|c|c|c|c|}
\hline \multirow[b]{2}{*}{ 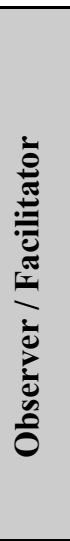 } & \multirow[b]{2}{*}{ 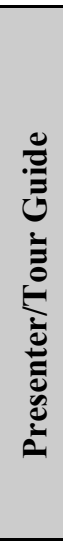 } & \multirow[b]{2}{*}{ Name } & \multirow[b]{2}{*}{ Affiliation } & \multirow[b]{2}{*}{ Email } & \multicolumn{10}{|c|}{ Expertise } \\
\hline & & & & & 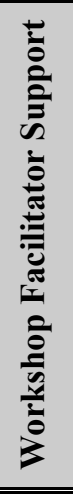 & 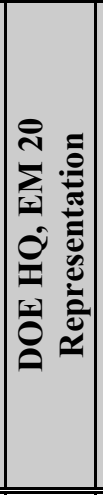 & 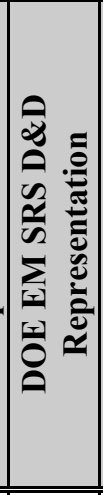 & 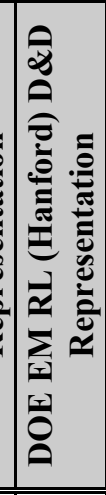 & 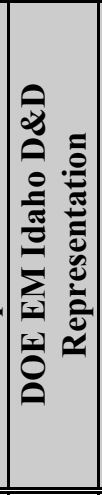 & 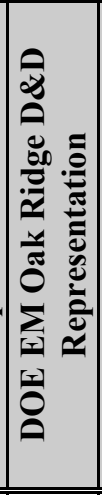 & 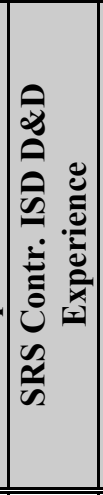 & 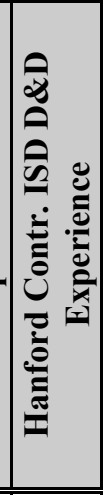 & 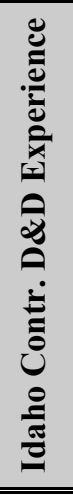 & 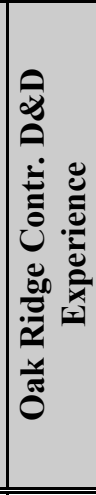 \\
\hline & $\mathbf{X}$ & Bill Austin & SRNS & william.austin@srs.gov & & & & & & & $\overline{\mathbf{X}}$ & & & \\
\hline $\mathbf{X}$ & & Robbie Bates & SRNS & robbie.bates@srs.gov & & & & & & & & & & \\
\hline & $\mathbf{X}$ & Helen Belencan & DOE-SR & helen.belencan@srs.gov & & & $\mathbf{X}$ & & & & & & & \\
\hline & $\mathbf{X}$ & Chris Bergren & SRNS & chris.bergren@srs.gov & & & & & & & $\mathbf{X}$ & & & \\
\hline & $\mathbf{X}$ & Sam Bhattacharyya & SRNL & samit.bhattacharyya@srnl.doe.gov & & & & & & & $\mathbf{X}$ & & & \\
\hline $\mathbf{X}$ & & Peter Blaney & PEC & pblaney@pec1.net & $\mathbf{X}$ & & & & & & & & & \\
\hline & $\mathbf{X}$ & JD Chiou & SRNS & JYH-DONG.CHIOU@SRS.GOV & & & & & & & $\mathbf{X}$ & & & \\
\hline & $\bar{X}$ & Yvette Collazo & DOE-HQ & yvette.collazo@hq.doe.gov & & $\mathbf{X}$ & & & & & & & & \\
\hline $\mathbf{X}$ & & Bill Erickson & DOE-SR & bill.errickson@srs.gov & & & $\mathbf{X}$ & & & & & & & \\
\hline $\mathbf{X}$ & & Trevor Foley & SRNL & trevor.foley@srnl.doe.gov & & & & & & & & & & \\
\hline & $\mathbf{X}$ & Grady Friday & SRNS & grady.friday@srs.gov & & & & & & & $\mathbf{X}$ & & & \\
\hline $\mathbf{X}$ & & John Gilmour & SRNS & chris.bergren@srs.gov & & & & & & & $\mathbf{X}$ & & & \\
\hline $\mathbf{X}$ & & John Gladden & SRNL & john.gladden@srnl.doe.gov & $\mathbf{X}$ & & & & & & $\mathbf{X}$ & & & \\
\hline $\mathbf{X}$ & & Tim Jannik & SRNL & tim.jannik@srnl.doe.gov & $\mathbf{X}$ & & & & & & $\mathbf{X}$ & & & \\
\hline $\mathbf{X}$ & & Steve Loftus & PEC & sloftus@pec1.net & & & & & & & & & & \\
\hline & $\bar{X}$ & Tony Long & SRNS & tony.long@srs.gov & & & & & & & $\mathbf{X}$ & & & \\
\hline $\mathbf{X}$ & & Rick Martinez & PEC & rmartinez@pec1.net & $\mathbf{X}$ & & & & & & & & & \\
\hline
\end{tabular}




\begin{tabular}{|c|c|c|c|c|c|c|c|c|c|c|c|c|c|c|}
\hline \multirow[b]{2}{*}{ 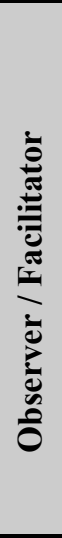 } & \multirow[b]{2}{*}{ 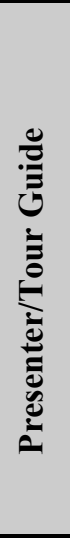 } & \multirow[b]{2}{*}{ Name } & \multirow[b]{2}{*}{ Affiliation } & \multirow[b]{2}{*}{ Email } & \multicolumn{10}{|c|}{ Expertise } \\
\hline & & & & & 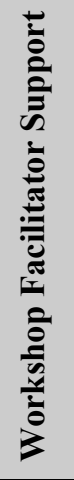 & 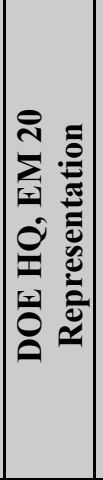 & 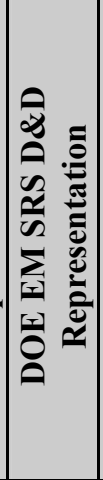 & 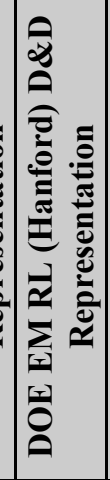 & 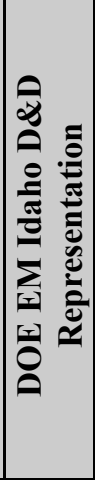 & 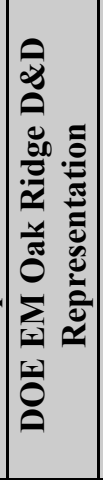 & 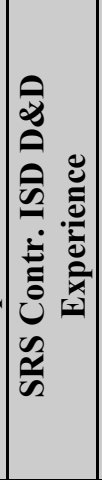 & 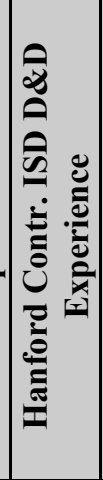 & 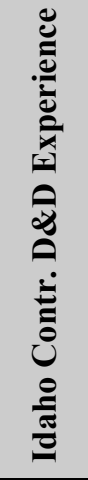 & 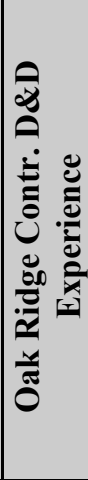 \\
\hline $\mathbf{X}$ & & Erick Reynolds & PEC & ereynolds@pec1.net & $\mathbf{X}$ & & & & & & $\mathbf{X}$ & & & \\
\hline $\mathbf{X}$ & & Greg Rucker & SRNS & greg.rucker@srs.gov & & & & & & & $\mathbf{X}$ & & & \\
\hline $\mathbf{X}$ & & Joe Santos & SRNL & joe.santos@srnl.doe.gov & & & & & & & $\mathbf{X}$ & & & \\
\hline & $\mathbf{X}$ & Mark Shaw & DOE-ID & shawrm@id.doe.gov & & & & $\mathbf{X}$ & & & & $\mathbf{X}$ & & \\
\hline $\mathbf{X}$ & & Deborah Shedrow & SRNL & deborah.shedrow@srnl.doe.gov & $\mathbf{X}$ & & & & & & & $\mathbf{X}$ & & \\
\hline $\mathbf{X}$ & & Chuck Urland & PEC & curland@pec1.net & $\mathbf{X}$ & & & & & & & & & \\
\hline $\mathbf{X}$ & & Dave Yannitell & SRNS & david.yannittell@srs.gov & & & & & & & & & & \\
\hline & $\mathbf{X}$ & Lloyd Zinsli & Hanford CPRC & Lloyd_C_Zinsli@rl.gov & & & & & & & & $\mathbf{X}$ & & \\
\hline
\end{tabular}




\section{Appendix C. Workshop Needs Statements Details}

\section{C.1 Need 1: In-Tank Characterization with Isotopic Discrimination}

\section{C.1.1 Need}

The ability to perform in-tank characterization with isotopic discrimination would provide timely data for project planning and decision making.

\section{C.1.2 Justification}

There are hundreds of tanks and sumps associated with facilities planned for ISD that require characterization prior to closure. Current protocols require mixing of tank liquids and sludge and retrieving multiple samples for laboratory analysis. The cost can be as much as $\$ 200,000$ per sample. Also, turnaround time for sample analysis can be several weeks. Sampling of sumps follows a similar approach.

\section{C.1.3 Technical Approach}

The objective of this task is to use an integrated systems approach to develop and demonstrate field deployable in situ characterization technologies that can be deployed in tanks or sumps to determine total radiation levels and determine the specific isotopic content.

Identify and demonstrate technologies and approaches that can be used to characterize residual liquids and sludge in tanks and sumps:

Identify candidate tanks and/or sumps for demonstration of potential characterization technologies

Identify and evaluate possible in situ characterization technologies that meet the specific conditions and requirements of identified tanks and/or sumps

Evaluate readiness of technologies for site-specific field deployment

Demonstrate selected technologies in targeted tanks/sumps

Document cost and performance data

\section{C.1.4 Task Identification}

Identify Demonstration Site and Performance Criteria: Identify the tank(s) and/or sump(s) for demonstration of the selected technology (ies) and the operating and performance criteria for the technology (ies) to be demonstrated. The initial demonstration may be in a tank or sump that has been previously characterized. This would help limit the cost of site support and provide quality data for comparison of the demonstration results.

Technology Identification and Assessment: Identify the technologies suitable to meet site specified operating and performance criteria and assess the readiness of those technologies for field deployment.

Identify commercially available in situ characterization technologies, their ability to meet specified criteria, and any additional development or engineering needed. 
Field Demonstration: Conduct field demonstration of selected technology in one or more tanks and/or sumps.

Report: Document cost and performance data for field demonstration. Complete draft and final report documenting the cost and performance data from the technology demonstration.

\section{C.2 Need 2: Assessment of the State-of-the-Art for Field Deployment Systems for Difficult COCs}

\section{C.2.1 Need}

Field instruments that require introduction of a sample are available for most Contaminants of Concern (COCs). The real interest is in remote sensing to find and quantify amounts of COCs.

\section{C.2.2 Justification}

Providing remote access for sensors would provide accurate contaminant classification while improving worker safety by reducing exposures and reducing costs of mitigating worker risk.

\section{C.2.3 Technical Approach}

The objective of this task is to provide remote sensor capability for difficult COCs that are important from a risk or Performance Assessment (PA) perspective. These COCs of interest often include:

- Low-energy, longer-lived radionuclides

- SNM in situ (inside equipment, inside pipes embedded in walls and floors)

- $\mathrm{SNM}$ in high radiation environments

- RCRA metals (e.g., Be)

This technical assessment should include how DOE sites are currently handling sampling, indicator species, and isotope ratios for quantification of these COCs.

\section{C.2.4 Task Identification}

Identify demonstration site and performance criteria: Identify the project sites with typical remote access needs for demonstration of the selected technology (ies) and the operating and performance criteria for the technology (ies) to be demonstrated. The initial demonstration may be at a site that has been previously characterized. This would help limit the cost of site support and provide quality data for comparison of the demonstration results.

Technology Identification and Assessment: Identify the technologies suitable to meet site specified operating and performance criteria and assess the readiness of those technologies for field deployment.

Identify commercially available in situ characterization technologies, their ability to meet specified criteria, and any additional development or engineering needed. 
Field Demonstration: Conduct field demonstration of selected technology in one or more tanks and/or sumps.

Report: Document cost and performance data for field demonstration. Complete draft and final report documenting the cost and performance data from the technology demonstration.

\section{C.3 Need 3: Degradation Rates and Sorption Behavior}

\section{C.3.1 Need}

The objective of this task is to obtain realistic and technically justifiable estimates of 1) degradation/corrosion rates for the various engineered materials associated with ISD facilities, and 2) sorption coefficients, solubilities, etc. for long-lived radionuclides in various structural materials and possible fill materials. Better estimates of these parameters will greatly reduce the uncertainties of risk predictions in the contaminant transport models.

\section{C.3.2 Justification}

Activated stainless steel contains much of the activation product inventory in reactor buildings and other radiological facilities; therefore a key need is to obtain a set of corrosion rates for stainless steel that is exposed to air, water, and grout environments. Additional materials for which degradation/corrosion rates are desired include:

$\begin{array}{ll}\text { Carbon steel } & \text { (contaminant source) } \\ \text { Concrete } & \text { (contaminant source) } \\ \text { Oxidized grout } & \text { (possible fill material) } \\ \text { Reduced grout } & \text { (possible fill material) }\end{array}$

It is also desired to obtain improved sorption coefficients $\left(\mathrm{K}_{\mathrm{d}} \mathrm{s}\right)$, solubilities, etc. for selected radionuclides, in concrete and in materials being considered for fill. Elements which may benefit from additional study include:

Ag, C, Cl, I, Ni, Nb, Mo, Tc, U, and TRU

Estimated rates must be applicable to specified chemical environments.

\section{C.3.3 Technical Approach}

For both the degradation/corrosion issue and the contaminant chemistry problem, materials must be considered with respect to a specified surrounding chemical environment. Studies are needed for the situations listed below.

Degradation/corrosion of steel or concrete in contact with: 
- aerated water

- anoxic water

- soil

- grout

- air

Contaminant chemical behavior in:

- soil

- grout (oxidized or reduced)

- fly ash

- other possible amendments

- air

For concrete, considerations of degradation rate should include estimates of the extent to which contaminant transport via fracture flow might be important, relative to transport by pervasive flow.

\section{C.3.4 Task Identification}

\section{Identify Appropriate Experiments.}

Consult with stakeholders to identify the most important needs with respect to degradation/corrosion rates and chemistry.

Identify the methods and experimental set-ups (laboratory or field) that would lead to the best estimates of the desired degradation/corrosion rates and sorption coefficients, solubilities, etc. Because of the long time frames associated with these parameters, applicable acceleration methods must be considered.

Retardation Technology Identification and Assessment: Identify the technologies that explore the extent to which the degradation/corrosion of contaminated materials could be retarded by altering their chemical environments with coatings, jackets, or surrounding them with other, non-traditional materials.

Report: Document the findings in technical reports and/or peer-reviewed journals.

\section{C.4 Need 4: Long Term Materials Performance Studies}

\section{C.4.1 Need}

Well defined long term (greater than 500 years) performance data for Portland cementbased materials. 


\section{C.4.2 Justification}

The ISD end state is a viable option for disposition of contaminated robust concrete structures. The current practice for the preparation of these structures for ISD is to fill them with grout to immobilize residual contaminants. The basis for this costly practice has come under question. A better understanding of the long term performance of the concrete materials (in terms of providing both containment and stability) may enable removal of conservatisms from modeling assumptions that drive costly ISD implementation approaches.

\section{C.4.3 Technical Approach}

The objective of this task is to conduct long term performance studies on Portland cement-based materials to provide a better understanding of their long term behavior in the anticipated environment(s) for ISD projects.

The study will focus on Portland cement-based materials used in the construction of the candidate facilities, as well as the grout materials used for filling these structures. Tests will be designed to determine the performance period where these materials can safely and effectively maintain structural stability and/or containment of residual contaminants.

This work should be coordinated to supplement (and draw on the lessons learned from) related work being conducted by the Cementitious Barriers Partnership Project (CBP).

Close cooperation (needs, technical issues, resources, and funding) between EM-23, EM21 and EM-11 is recommended because all of these organizations have projects that involve cementitious barriers for radionuclide containment. EM-21 established the Cementitious Barriers Partnership Project, (CBP) in 2008 to address long term performance needs of these materials. The CBP is a multi-disciplinary, multi-institution cross cutting collaborative effort supported by the DOE to develop a reasonable and credible set of tools to improve understanding and prediction of the structural, hydraulic and chemical performance of cementitious barriers used in nuclear applications. The period of performance is $>100$ years for operating facilities and $>1000$ years for waste management.

The CBP partners, in addition to the DOE, are the U.S. Nuclear Regulatory Commission (NRC), the National Institute of Standards and Technology (NIST), SRNL, Vanderbilt University (VU) / Consortium for Risk Evaluation with Stakeholder Participation (CRESP), Energy Research Center of the Netherlands (ECN), and SIMCO, Technologies, Inc.

The project focus includes reducing uncertainties associated with current methodologies for assessing cementitious barrier performance and increasing the consistency and transparency of the assessment process. The results of this project will support long term performance predictions and performance-based decision making and are applicable to 
several of the strategic initiatives in the DOE Environmental Management Engineering \& Technology Roadmap.

\section{C.4.4 Task Identification}

The study should be conducted on representative material samples in simulated environments to define the performance period for the materials. Close coordination with the CBP Project should be employed to prevent duplication of effort and to help define the investigation approach. The major steps in the study would include:

- Identify cementitious materials (i.e., foundation, wall, slab, and above-grade reinforced concrete structure members) representative of candidate ISD structures that should be evaluated.

- Identify the characteristics of the physical environments that these materials will be exposed to during the ISD lifetime.

- Define the parameters that will be used to quantify the performance (in terms of providing contaminant containment and providing structural stability) of these materials.

- Conduct simulated "aging" tests to determine the performance characteristics of the materials in the various environments. The objective being to identify at what point(s) in time the materials a) loose their ability to provide effective containment of contaminants, and b) lose their ability to maintain structural integrity and eventually collapse.

- Confirm the results through computer modeling. Confer with the CBP Project as needed.

- Document the findings in a report.

\section{C.5 Need 5: Release of Activation Products from Corroded Stainless Steel}

\section{C.5.1 Need}

Define the release mechanism and release rates for activation products from corroded carbon steel and stainless steel components. Provide parameters for use in performance assessments (phase changes and phase volumes, solubility, $\mathrm{K}_{d} \mathrm{~s}$, etc.)

\section{C.5.2 Justification}

A better understanding of the release mechanism for activation products from corroded carbon and stainless steel is needed to quantify the source term used in release calculations for ISD projects. More accurate predictions of the amount that will be released and the time frame for the release may enable a reduction in the conservatism in modeling assumptions thus allowing implementation of more streamlined and costeffective "engineered" measures. 


\section{C.5.3 Technical Approach}

The objective of this task is to conduct material science studies on activated or surrogate activated carbon steel and stainless steel specimens to provide a better understanding of the manner and timing in which activation products are released from these materials.

Simulated material studies, similar to the work conducted by the U.S. NRC to support the licensing of High Integrity Containers for LLW burial, should be conducted to provide the necessary data.

\section{C.5.4 Task Identification}

The study should be conducted on representative material samples in simulated environments to define the release mechanisms. The major steps in the study would include:

- Identify stainless and carbon steel specimens representative of equipment typically found in candidate ISD structures that should be evaluated. If feasible, obtain actual coupon samples from existing components (i.e., reactor vessel, canyon process tank, etc.).

- Identify the characteristics of the physical environments that these materials will be exposed to during the ISD lifetime.

- Design the tests to simulate the aging process in the expected ISD environments. Parallel tests should be conducted with the specimens encased in grout to understand the affects of grout chemistry on the release mechanisms.

- Conduct the tests. The objective being to establish an activation product release profile over time.

- Document the findings in a report.

\section{C.6 Need 6: Design Guide for Sealing/Filling ISD Facilities}

\section{C.6.1 Need}

Develop guidance for the identification of strategies, functional requirements and designs for fill and seal of ISD facilities.

\section{C.6.2 Justification}

Most, if not all, ISD facilities will be sealed and filled to some degree. This is a significant and critical design issue that determines the degree of certainty by which residual contaminants in the closed facility will remain sequestered and for how long. This decision making appears to occur on a case-by-case basis dependent on the local regulatory environment and the experience of the D\&D personnel involved. 


\section{C.6.3 Technical Approach}

Designs are needed for both sealing and filling. Generic performance and functional requirements need to be specified/identified to allow the designer to prepare material specifications and drawings. These requirements need to be aligned with generic hazards and specify a preferred sequence of hazard identification versus engineered control. A flow sheet or "design guide" would be beneficial to a designer/engineer tasked with preparing a facility for ISD.

'Classes' of ISD targeted facilities should be identified based on facility structural integrity, design characteristics and level/type of contamination to be left behind during ISD (e.g. short vs. long lived isotopes). Relationships among the integrity of the existing structure and the required duration of hazard isolation should be developed to identify the extent and rigor of mitigative measures to be required through seal and fill technologies. From these criteria, guidance can be developed to ensure that appropriate, but not excessive, design requirements can be identified for facilities to be decommissioned In Situ.

\section{C.6.4 Task Identification}

- Develop criteria for identifying classes of facilities destined for ISD within the complex (in progress).

- Based on results of ongoing surveys, classify all facilities into appropriate categories.

- Determine commonalities among hazard exposure pathways, source of contaminants, pathways of release from the facility, and timing of release.

- Identify sealant materials that ensure reliable containment against the contaminant and throughout the required containment interval.

- Identify fill materials that provide required properties of:

- Structural fill or support

- Hydrologic containment

- Contaminant stabilization

- Develop guidance document and guides for identification of design requirements and recommended materials for sealing and filling of ISD facilities.

\section{C.7 Need 7: Seal/Fill Material 'Toolbox'}

\section{C.7.1 Need}

Information on, and examples of, fill material (mix designs and properties) and sealing materials (products and properties) that meet typical requirements for ISD applications with supporting documentation for use by designers and systems engineers (alternatives studies) across the DOE complex. 
More specifically the need for two "Toolbox" documents which summarize the information listed below was identified.

Fill Material Toolbox

- Functional performance requirements for infills and backfills

- Generic or typical fill materials which meet the placement and cured requirements

- Properties of types of fill materials

- Long term performance and property evolution of fills over long times (emphasis on portland cement-based fills)

- Production and placement requirements of various types of fills

- Non-radioactive construction experience using various types of fills

- Pros and cons comparison of the types of fills

Sealing / Fixative Materials Toolbox

- Sealing material needs / requirements for objects and buildings, i.e, openings in the buildings themselves (doors, ventilation ducts, electrical and water lines, joints, cracks, etc.)

- Fixative material needs / requirements for activities that support ISD activities including to: facilitate particulate consolidation and removal, fix contaminants during ISD operations, or address other short or long term need

- Functional performance requirements of sealants for crack repair and for fixative materials

- Typical sealants and fixative materials (specific examples of commercially available materials).

- Properties of types of sealants and fixative materials

- Performance and property evolution of sealants and fixative materials over time and under relevant expected conditions

- Production and placement requirements of various types of sealants and fixative materials

- Non-radioactive construction experience using various types of sealants and fixative materials

- Pros and cons comparison of the types of sealants and fixative materials

Opportunities for enhancing performance of the various types of fill should be addressed, as well as areas for near term (1-3 years) and long term (1-4 years) testing to reduce performance assumptions.

\section{C.7.2 Justification}

A materials tool box for ISD activities is necessary for planning, designing, and performing ISD activities. 
100,000 's of cubic meters of infill and back fill materials will be used for ISD throughout the DOE complex.

Fixing contaminants for removal and/or to reduce personnel exposure and spread of contamination during ISD activities is essential.

Sealing openings to buildings (doors, ventilation ducts, electrical and water lines, structural joints and cracks, as well as assessing moisture transport through intact walls is an essential part of ISD projects.

\section{C.7.3 Technical Approach}

The technical approach consists of:

- Identifying generic and typical ISD applications and requirements for fills, sealing materials, and fixatives based on experience and projects in the DOE complex.

- Conducting a literature review of: fill, sealing, and fixative materials used for ISD and related activities and to compile the information in a "Toolbox" document format for use by designers and systems engineers (alternatives studies) across the DOE complex.

\section{C.7.4 Task Identification}

\section{Sealing Materials "Toolbox"}

- Identify information resources: Sources of information include: publications from the DOE sites and communication with project managers and technical experts in the DOE complex.

- Identify ISD activities and material needs and performance requirements

- Identify materials that have been or are planned to be used for ISD applications

- Compile and summarize the information

- Issue Report

\section{Fill Materials "Toolbox"}

- Identify information resources: Sources of information include: publications from the DOE sites and communication with project managers and technical experts in the DOE complex.

- Identify ISD activities and material needs and performance requirements

- Identify materials that have been or are planned to be used for ISD applications

- Compile and summarize the information

- Issue Report 


\section{C.8 Need 8: Energy and Environmentally Responsive Fill Material Designs}

\section{C.8.1 Need}

Leadership in Energy and Environmental Design (LEED) for high volume ISD fill materials.

\section{C.8.2 Justification}

The high volume of infill and back fill materials that will be used for the 100,000's of cubic meters of material used in the DOE ISD projects warrants LEED consideration. DOE is heavily invested in LEED technology to reduce carbon emissions and the use of fossil fuels.

\section{C.8.3 Technical Approach}

The technical approach consists of identifying a base case(s) for fill materials that meets the requirements for bulk fill and using standard LEED practices for:

- Assessing the carbon emissions and fossil fuels consumption involved in producing these materials

- Identifying alternatives or options for reducing the fossil fuel consumption and carbon emissions involved in producing these materials.

The U.S. Green Building Council (USGBC) LEED practices will be applied where applicable. If they are inadequate for capturing the full carbon emissions, fossil fuel consumption, innovative approaches need to be developed and calculation expanded.

\section{C.8.4 Task Identification}

- Identify reference case fill materials for evaluation

- Evaluate carbon emissions and fossil fuel use for production and placement of the reference case materials

- Develop alternative lower carbon emissions and fossil fuel use options

- Develop performance comparison charts

- Compile and summarize the information

- Issue Report

- Publicize DOE ISD LEED activities.

\section{C.9 Need 9: Design Monitoring Into ISD Facility}

\section{C.9.1 Need}

A monitoring system should be developed that would demonstrate whether the ISD performance meets program goals and conforms to project planning predictions. 


\section{C.9.2 Justification}

The early design and implementation of a comprehensive monitoring scheme for an ISD structure is seen as a benefit in the near term (20 to 50 years) to demonstrate that the ISD design is functioning as planned to isolate the source term. A series of robust sensors distributed throughout the facility could provide time dependent information about performance, thus helping to validate the modeling assumptions and structural performance.

\section{C.9.3 Technical Approach}

The parameters in the following table would need to report out to a control panel, exterior to the facility, that could be visited periodically (e.g., annually to start then growing into part of the CERCLA required 5 year inspection) and the data download. The monitors would be installed in the ISD facility as part of the project work with some duplication of function to allow the data to provide a picture of how the source term confinement is performing over time.

- The sensors would be buried / installed throughout the structure, in duplicate / triplicate in most cases.

- The design operating life of the sensor and download interface should be at least 50 years, but longer would clearly be a preference.

- Must be passive with exterior power source (energized when collecting data only is preferred).

- Numerical output/quantitative data is most useful for the monitored parameters. One time sensors can provide information when collecting quantitative data is not possible.

- Standardized interface for collected data is critical and should be able to be updated without entry to the facility or access to the sensor. 


\begin{tabular}{|l|l|}
\hline $\begin{array}{l}\text { Parameter to be } \\
\text { monitored }\end{array}$ & Data use in demonstrating ISD performance \\
\hline Strain and Stress & Materials structural failure, cracking, settling \\
\hline Subsidence & Indicate subsidence by placing targets on the surface of the building \\
\hline Oxygen & $\begin{array}{l}\text { Aid in the identification of overall corrosion potential and } \\
\text { geochemical environment. }\end{array}$ \\
\hline $\mathrm{pH}$ & $\begin{array}{l}\text { Identify presence of water, corrosivity, metal corrosion, } \\
\text { cementitious materials degradation and geochemical environment } \\
\text { can aid in the overall corrosion potential/progress. }\end{array}$ \\
\hline $\begin{array}{l}\text { Electrical } \\
\text { Conductivity }\end{array}$ & $\begin{array}{l}\text { Identify presence of water, the amount of soluble materials, the } \\
\text { geochemical environment, or carbonation can aid in the overall } \\
\text { corrosion potential/progress. }\end{array}$ \\
\hline Temperature & Can be an indicator of water movement \\
\hline Moisture & Identify the presence of water or in leakage to the structure. \\
\hline Gamma Radiation & $\begin{array}{l}\text { Monitor any change (up or not down as expected based on decay) } \\
\text { within the structure to assess movement of the source term. }\end{array}$ \\
\hline Sulfate & Monitor increase in sulfates as an indicator of infiltration \\
\hline Corrosion Potential & Status of steel reinforcement bars and corrosion of metal structures \\
\hline Acoustic change & Provides information on cracking and water infiltration \\
\hline Carbon dioxide & Information on carbonation of cementitious materials \\
\hline
\end{tabular}

\section{C.9.4 Task Identification}

Identify demonstration site and performance criteria: Identify the project site(s) for demonstration of the selected sensor technology(ies) and the operating and performance criteria for the technology(ies) to be demonstrated. The candidate sites do not need to be exclusively in situ, only appropriate for demonstrating the sensor capabilities in satisfying the monitoring program goals. Where sensor objectives are unique to in situ conditions, selected demonstration sites should reflect those conditions.

Technology Identification and Assessment: Identify the technologies suitable to meet site specified operating and performance criteria and assess the readiness of those technologies for field deployment.

Identify commercially available in situ sensor technologies, their ability to meet specified criteria, and any additional development or engineering needed.

Field Demonstration: Conduct field demonstration of selected technology in one or more locations.

Report: Document cost and performance data for field demonstration. Complete draft and final report documenting the cost and performance data from the technology demonstration. 


\section{C.10 Need 10: Measures to Improve Communication of Risk Assessment Modeling Approaches, Data and Lessons Learned}

\section{C.10.1 Need}

The ability to have access to complex-wide experience, data and modeling tools, and lessons learned to support risk assessments for facility closure and ISD. Note that this need discussion is focused on risk assessment aspects, but such a system could also be used to share information related to another need identified at the ISD Workshop.

\section{C.10.2 Technical Justification}

Senior management in DOE-EM have recognized risks associated with inconsistencies in modeling approaches and assumptions being applied at individual DOE Sites and complex-wide. Also, as more challenging closure projects are being addressed, it is becoming necessary to use more complex models than are typically used for CERCLA risk assessments. Experience with more complex modeling approaches and data used for performance assessments for disposal facilities and tank closures can be shared with those conducting assessments for ISD. Furthermore, modeling approaches and data from ISD at one facility can be shared with those responsible for ISD of other facilities. Fostering a means to efficiently share information provides for more cost effective and robust modeling in support of ISD and will help to reduce the potential for significant inconsistencies in modeling approaches.

This activity is not unique to ISD and has also been discussed in the context of PAs being conducted for disposal facilities, tank closures and risk modeling being conducted in support of NEPA, CERCLA, RCRA, etc. In this respect, there may be opportunities for shared funding across different programs.

\section{C.10.3 Technical Approach}

The objective of this task is to upload, organize, and disseminate information that would be useful for people conducting risk assessments in support of ISD. The types of information to be maintained could include: parameter values used in assessments, listing of available experimental data, modeling approaches, lessons learned, computer codes, subject matter experts, regulator preferences, analysis needs, links to key websites, etc. It has been suggested that such a system could be constructed in a manner similar to Wikipedia, where individuals would be able to load information onto the system. Pros and cons of this concept will need to be discussed. Initially, the system may simply include a number of reports that are categorized based on the information that can be obtained. In the future, the possibility of extracting information from reports and consolidating information from a variety of sources into a structured database could be considered. The need for and level of effort associated with reviews of different types of information to be included in the system would be assessed as part of the project. 


\section{C.10.4 Task Identification}

This information system would be developed in a phased approach. There could be coordination and expansion to address similar needs for risk assessment and performance assessment across the DOE Complex (e.g., Performance Assessment Community of Practice and Performance Assessment Assistance Team concepts being discussed with EM-11 and EM-21). The major steps include:

- Basic Framework

- Identify types and key sources of specific information that will form the initial package (e.g., information on subject matter experts, key references, example input parameters and modeling assumptions for key areas of need [e.g., cement degradation, corrosion, etc.], lessons learned).

- Review similar web portals developed for other applications and identify beneficial features.

- Requirements Identification and System Design

○ Develop requirements for the system (e.g., capability for external users to add/access information when logged in, security requirements, types of files, database structure for SME information and lessons learned, categories and pedigrees of information to be included (i.e., data, model assumptions, lessons learned).

○ Develop initial design for the system (e.g., page layouts, reports, databases, queries, menus, links to other sites, etc.).

- Implementation

- Consult with practitioners at DOE sites to obtain initial set of references for data, modeling assumptions, lessons learned, list of SMEs, etc.

- Roll out limited version for testing with initial set of information.

- Make modifications based on initial use of the system.

- Conduct regular expert reviews of information included on the web site (frequency depending on funding), annual lessons learned meetings, issue quarterly newsletters highlighting important developments and new information, etc.

\section{C.11 Need 11: Technical Resources Needed for ISD}

\section{C.11.1 Need}

Technical Guidance/Resource documents specifically related to ISD facilities need to be developed and disseminated throughout the DOE Complex. At a minimum, the following four areas should to be addressed: Design Concepts, Fill Materials, Barriers, and Physical/Chemical Properties.

\section{C.11.2 Justification}

The potential synergies between waste isolation performance, materials property evolution, and costs could likely result in avoiding mistakes already experienced and lead to more effective engineering designs for ISD facilities. Without existing benchmarks and 
adaptive thinking, ISD (and other) projects are generally approached as a "first-of-akind" effort. ISD projects are too often designed by engineers without experience with performance assessment limitations and largely based on initial materials properties. Tight time schedules and shifting priorities make it difficult to engage groups of experts in individual ISD designs.

A set of guidance documents would facilitate implementation of better designs by practicing engineers who are by necessity generalists. While cost savings through an enlightened engineering design process are likely to be significant, they can only be assessed after the fact on a case by case basis. The synergies would also contribute to compliance with ALARA by improving waste isolation.

\section{C.11.3 Technical Approach/Task Identification}

The following technical resource documents should be developed and disseminated throughout the DOE Complex. These could be a set of four separate documents, one large document, or combinations thereof.

Design Concepts: The design concept document would combine an understanding of performance assessment, materials performance, and engineering to develop a set of engineering design concepts for ISD facilities. The focus would be on the options available for optimizing long term waste isolation performance at low cost with consideration of desirable features such as reversibility and irretrievability. The work would consider existing designs along with new concepts based upon technical analysis of long term performance, feasibility, reliability, and cost.

Fill Materials: Many facility designs will utilize fill materials of some type. Examples are: cementitious materials, clay, sand, soil, rubble, and decommissioned equipment (and potentially a combination of these and other materials). Fill materials may function to provide long term structural reliability (avoiding subsidence); chemical conditioning to influence corrosion, solubility, and sorption; and/or permeability changes to influence water migration. The technical resource would summarize the current state of the art for these materials; explain their advantages, disadvantages, and proper use; and provide a bibliography of selected detailed references.

Other Barriers: Other barriers besides fill materials exist and should be considered in ISD. Examples are: geomembranes, asphalt layers, clay, epoxy, and metals. The technical resource would summarize the current state of the art for these materials; explain their advantages, disadvantages, and proper use; and provide a bibliography of selected detailed references.

Vetted Physical/Chemical Properties: Performance assessment modelers need to estimate a variety of model parameters. This can be a difficult and lengthy process. When individual groups do this separately there is likely to be inconsistency in assumptions between different portions of the DOE Complex and perhaps differences between these assumptions and references preferred by regulatory agencies. These differences lead to 
unnecessary model iterations that cause delays and accelerate costs. A carefully peer reviewed source of model parameters (e.g., $\mathrm{K}_{\mathrm{d}}$ in concrete, corrosion rate of stainless steel) will lower DOE Complex wide costs while improving consistency.

\section{C.12 Need 12: Problem: Significant Sample Analysis Is Required to Establish Ratios for Many COCs}

\section{C.12.1 Need}

Data available from existing sample analyses should be compiled to establish baseline uncertainty ratios for low-energy, longer-lived radionuclides.

\section{C.12.2 Justification}

These ratios can be used in conjunction with a few representative samples to validate the ratios for low-energy, longer-lived radionuclides on a new project. If samples fall within the baseline the overall sample and analysis plan should be able to be reduced, particularly if results are being used to provide bounding values.

\section{C.12.3 Technical Approach}

The objective of this task is to provide a resource for determining ratios of certain COCs on a new project without the need for extensive sample analysis. The potential isotopes for which the ratios would be helpful in reducing a new project's overall sample and analysis plan should be identified. For the scoped isotopes, the project parameters that define the criteria for applicable ratios need to be determined. Under these resource definitions, the results from available sampling analyses should be compiled and correlated with the project parameters to apply appropriate isotopic ratios on a new project. As additional isotopes and parameters are identified as being necessary for accurately assessing project conditions, the ratio database should be further developed accordingly.

\section{C.12.4 Task Identification}

Identify demonstration site and performance criteria: Criteria for evaluating candidate projects to determine whether they would make a good test case will have to be defined. Candidate projects against which the ratio database method can be tested should be identified. The candidate projects may be new or having previously undergone a traditional sample and analysis plan. The test cases will be assessed under a traditional method, as well as using the ratio database. The accuracy and completeness of the ratio database compared to extensive sampling will determine the project stages/uses for which the resource would be appropriate.

Field Demonstration: Success will be demonstrated through project test cases. 
Report: Complete draft and final report documenting the baseline uncertainty ratios for low-energy, longer-lived radionuclides and providing guidance on project uses for which the ratios may be applied.

\section{C.13 Need 13: DOE Order 470.4-6 Nuclear Material Control and Accountability}

\section{C.13.1 Need}

Revise DOE Manual DOE M 470.4-6, Nuclear Material Control and Accountability, to be more in line with current D\&D practices.

\section{C.13.2 Justification}

Many of the facilities that are candidates for ISD have been involved in some manner in the processing of special nuclear material (SNM). Considerable effort is expended to measure, quantify, and/or remove material hold-up during decommissioning of these facilities as dictated by the current DOE Order for Nuclear Material Control and Accountability. A change in the requirements could provide significant savings in terms of project cost and schedule and personnel exposure by eliminating the need for costly and time consuming measurement techniques and "mining" work to recover hold-up.

\section{C.13.3 Technical Approach}

Three specific issues are to be addressed by the revision:

- The Order should be changed to allow the end state of the facility to drive the attractiveness level of residual holdup. An example of this would be grouting a facility which renders the SNM to attractiveness level "E," regardless of its original level.

- Currently the Order requires measurement of all SNM attractiveness level "E" to quantify holdup. The Order should be revised to allow use of process knowledge and engineering estimates in place of direct measurement to quantify the residual material.

- The Order should also be revised to allow leaving material greater than attractiveness level "E" in systems/facilities if the removal of the material exposes workers to hazardous hostile environments or has no economical value.

\section{C.13.4 Task Identification}

The DOE Order should be revised to adequately address the above stated issues. Some empirical justification may be required to demonstrate that these new approaches do not unduly compromise Safeguards and Security Program objectives or affect a facility's vulnerability. The revision process would include:

- Establish coordination with order owner. 
- Identify the actual section(s) within DOE M 470.4-6 that need to be revised to address the above identified issues.

- Draft language to affect the requisite change(s).

- Prepare the necessary justification to support the approval process.

- Solicit field input as needed to support the revision process.

- Submit the proposed document revision(s) through the appropriate DOE review and approval chain.

Incorporate the changes and re-issue DOE M 470.4-6.

\section{C.14 Need 14: Develop and Test Flowable Concrete/Grout Mixes for ISD Applications}

\section{C.14.1 Need}

Flowable Concrete and Grout Mixes are required for ISD of reactor, separation, and other DOE facilities with radioactive and hazardous contamination. Hundreds of thousands of cubic meters of fill material are required for ISD of DOE facilities. (At SRS, the estimate for $\mathrm{R}$ and $\mathrm{P}$ Reactors is over 100,000 cubic meters each.)

\section{C.14.2 Justification}

The above and below grade structures that make up reactor, separation, and other large contaminated DOE facilities need to be physically stabilized to prevent collapse or creation of a "bath tub" effect and chemically stabilize contaminants. Flowable fill materials are needed to reduce labor costs and to enhance ALARA. A menu of demonstrated flowable mix designs will facilitate designs of ISD activities, reduce costs and risks, and accelerate implementation.

\section{C.14.3 Technical Approach}

The objective of this task is to apply existing concrete technology for flowable and self consolidating concrete to designing fills with low hydration heat, zero bleed / segregation, and enhanced contaminant stabilization properties for ISD applications. The fill materials need to be tailored for underwater, pre-placed aggregate/debris, light and heavy weight, and bulk fill applications. Flows ranging from 6 to 30 meters are desirable.

The rheological properties of flowable concrete/grout fill materials will be measured using advanced concrete rheometer technology. Concrete / grout rheology is necessary for designing placement plans and sizing delivery lines and pumps. Since quantitative concrete rheology is a relatively new field, the National Institute of Standards and Testing will need to support this activity.

In addition to characterizing the rheology of "fresh concrete/grout," properties of the cured flowable concretes and grouts will be measured to support long term Performance Assessments and Risk Analyses. The properties of interest include: permeability, 
moisture retention, porosity, density, shrinkage, strength, and retention of contaminants of concern.

\section{C.14.4 Task Identification}

Identify ISD fill requirements for a typical applications and design a suite of candidate mixes: Identify performance requirements and specify fresh and cured properties. The fill materials need to be tailored for underwater, pre-placed aggregate/debris, light and heavy weight, and bulk fill applications. Flows ranging from 6 to 30 meters are desirable.

Design mixes to meet requirements: Design mixes to meet placement and cured property requirements. Collaborate with commercial suppliers of concrete chemical admixtures to identify the need for new/enhanced additives that will meet the ISD placement needs.

Measure Properties on a Series of Mixes: Collaborate with materials scientists at the National Institute of Standards and Technology to obtain quantitative measurements on concrete and grout rheology. Use the rheological data to specify pumping and placing equipment and flow rates.

Cured properties will be characterized as a function of time (up to at least 180 days and longer for durability studies). These data will be used to support long term Performance Assessments.

Design Monitoring Techniques: Monitoring techniques to support placement and performance will be developed.

Field Demonstrations of Placement Techniques: Conduct field demonstration of selected mixes and placement technologies that simulate ISD needs, e.g.:

- High volume flowable concrete for underwater placement,

- Neutral $\mathrm{pH}$ fill for reactor vessels that contain aluminum components. (Al metal reacts with portland cement and generates heat and hydrogen gas in addition to expansive corrosion products.)

- Low heat, low permeability flowable fill.

- Dry grout placement for in-situ solidification of standing water in basins.

Pre-placed aggregate / debris solidification or grouting.

Field Demonstration of Performance: Test beds will be designed, constructed, and instrumented to monitor long term performance of the ISD materials.

Report: Document cost and performance data for field demonstration. Complete report documenting the cost and performance data from the technology demonstration. 
